U.S. GEOLOGICAL SURVEY CIRCULAR 922-A

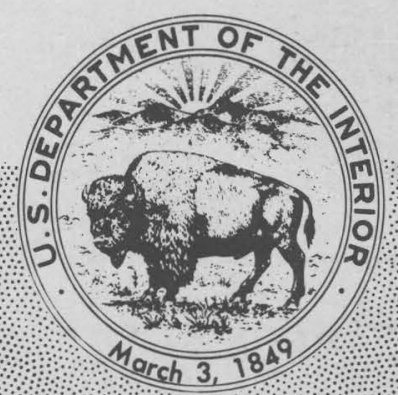

Assessment of Undiscovered
Conventionally Recoverable
Petroleum Resources of the
Northwest European Region 



\section{Assessment of Undiscovered Conventionally Recoverable Petroleum Resources of the Northwest European Region}

By Charles D. Masters and H. Douglas Klemme

U.S. GEOLOGICALSURVEY CIRCULAR 922 -A

Prepared in cooperation with Weeks Exploration Company under contract to the U.S. Geological Survey

A resource assessment and a brief description of the petroleum geology, including play distribution, that accounts for the petroleum accumulation in the North Sea and adjoining areas 


\section{Department of the Interior}

WILLIAM P. CLARK, Secretary

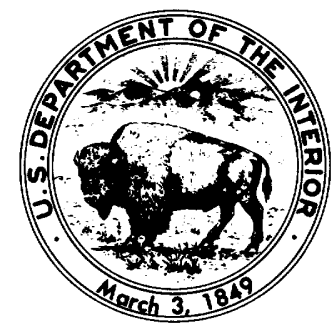

\section{U.S.Geological Survey}

Dallas L. Peck, Director 


\section{CONTENTS}

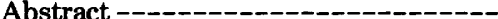

Introduction _-_-

Regional geology --

Petroleum geology --

Resource assessment -

Comments --

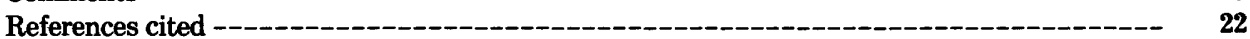

\section{ILLUSTRATIONS}

FIGURE 1. Map showing northwest European assessment region, including the North Sea --_---

2. Stratigraphic diagrams of selected petroleum provinces -

3. Map of Play I, central North Sea region -

4. Map of Play I, southern and southwest North Sea region -

5. Map showing potential petroleum basins, distribution of Jurassic Kimmeridgian source rocks in the North Sea between latitudes $59^{\circ} \mathrm{N}$. and $69^{\circ} \mathrm{N}$., inferred degree of maturity of source rock, and oil and gas fields --_-_-_-_-_-_-_-_-_-

6. Interpreted seismic stratigraphy and structure

7. Map showing potential petroleum basins, distribution of Jurassic Kimmeridgian source rock in the North Sea between latitudes $69^{\circ} \mathrm{N}$. and $76^{\circ} \mathrm{N}$., as well as the inferred degree of maturity of source rock ------

8. Interpreted seismic stratigraphy and structure -

9. Map showing Play II, southern North Sea region

10. Listing by size of fields attributed to Play I, further division of the occurrence of petroleum into four trap types, and a listing of fields attributable to each

11. Listing by size of fields attributed to Play II, a generalized diagram of trap type, and a listing of certain characteristics of the play

12. Discovery history by year of discovery and by field size according to time-lapse increment from year of award of concession

13-26. Graphs of northwest European region, aggregate recoverable:

13. Oil, subregions $A+B+C+D+E$

14. Total gas, subregions $A+B+C+D+E$

15. Oil, subregions $A+B+E$, south of $62^{\circ} \mathrm{N}$.

16. Total gas, subregions $\mathrm{A}+\mathrm{B}+\mathrm{E}$, south of $62^{\circ} \mathrm{N}$. -

17. Oil, subregions $\mathrm{C}+\mathrm{D}$, north of $62^{\circ} \mathrm{N}$.

18. Total gas, subregions $\mathrm{C}+\mathrm{D}$, north of $62^{\circ} \mathrm{N}$.

19. Oil, subregion A, Southern North Sea Basin

20. Total gas, subregion $A$, Southern North Sea Basin --_-_-

21. Oil, subregions B+E, Viking and Central Grabens -

22. Total gas, subregions $B+E$, Viking and Central Grabens

23. Oil, subregion $\mathrm{C}$, north of $62^{\circ} \mathrm{N}$., southern sector --

24. Total gas, subregion $\mathrm{C}$, north of $62^{\circ} \mathrm{N}$., southern sector --

25. Oil, subregion $\mathrm{D}$, north of $62^{\circ} \mathrm{N}$., northern sector --

26. Total gas, subregion $\mathrm{D}$, north of $62^{\circ} \mathrm{N}$., northern sector 


\section{TABLES}

TABLE 1. Assessment of undiscovered conventionally recoverable petroleum resources of the northwest European assessment region

2. Supplemental and comparative data relative to the resource assessment of the northwest European assessment region

3. Distribution by country and by subregion of undiscovered recoverable petroleum resources in the northwest European assessment region -

Page 
The World Energy Resources Program of the U.S. Geological Survey (USGS) is designed to develop reliable and credible estimates of undiscovered petroleum resources throughout the world. Initial program efforts have focused on the major producing areas of the world in order to gain a broad geological understanding of the characteristics of petroleum occurrence for purposes of resource assessment as well as for analysis of production potential. Investigations of production potential are carried out in cooperation with other U.S. Government agencies. Specifically, studies of the main exporting nations of the free world, of which this study is a part, are carried out in cooperation with the Foreign Energy Supply Assessment Program of the Department of Energy. The estimates represent the views of a U.S. Geological Survey study team and should not be regarded as an official position of the U.S. Government.

The program seeks to investigate resource potential at the basin level, primarily through analogy with other petroleum regions, and thus does not necessarily require current exploration information commonly held to be proprietary. In conducting the investigations, we intend to build a support base of publicly available data and geologic synthesis against which to measure the progress of exploration and thereby validate the assessment. Most of these investigations will lead directly to quantitative resource assessments. To be effective, resource assessment, like exploration, must be an ongoing process that takes advantage of changing ideas and data availability-the results produced are but progress reports reflecting on a state of knowledge at a point in time. Because the program is coordinated with the Geological Survey's domestic assessment program and uses similar assessment techniques, the user can be assured that a thread of consistency will permit comparisons between the various petroleum basins of the world, including those in the United States, that have been assessed in the overall Survey program.

In addition to resource estimates, the program provides a regional base of understanding for in-country exploration analysis and for analysis of media reports regarding the exploratory success or failure of ventures in studied areas.

Other USGS publications relating to the assessment of undiscovered conventionally recoverable petroleum resources include the following:

Open-File Report 81-0986-Assessment of conventionally recoverable petroleum resources of Persian Gulf basin and Zagros fold belt (ArabianIranian basin)

Open-File Report 81-1027-Assessment of conventionally recoverable petroleum resources, Volga-Urals basin, U.S.S.R.

Open-File Report 81-1142-Assessment of conventionally recoverable petroleum resources of Indonesia

Open-File Report 81-1143-Assessment of conventionally recoverable petroleum resources of northeast Mexico

Open-File Report 81-1144-Assessment of conventionally recoverable petroleum resources of southeastern Mexico, northern Guatemala, and Belize 
Open-File Report 81-1145-Assessment of conventionally recoverable petroleum resources of Trinidad

Open-File Report 81-1146-Assessment of conventionally recoverable petroleum resources of Venezuela

Open-File Report 81-1147-Assessment of conventionally recoverable petroleum resources of the West Siberian basin and Kara Sea basin, U.S.S.R.

Open-File Report 82-0296-Assessment of undiscovered conventionally recoverable petroleum resources of the Middle Caspian basin, U.S.S.R.

Open-File Report 82-1027-Assessment of undiscovered conventionally recoverable petroleum resources of the East Siberian basin, U.S.S.R.

Open-File Report 82-1056-Assessment of undiscovered conventionally recoverable petroleum resources of North Africa

Open-File Report 82-1057-Assessment of undiscovered conventionally recoverable petroleum resources of the Timan-Pechora basin, U.S.S.R., and Barents-northern Kara shelf

Open-File Report 83-0598-Assessment of undiscovered conventionally recoverable petroleum resources of Northwestern, Central, and Northeastern Africa

Open-File Report 83-0801-Assessment of undiscovered conventionally recoverable petroleum resources of onshore China

These reports are available from Open File Services Section, Branch of Distribution, USGS, Box 25425, Federal Center, Denver, CO 80225. 


\title{
Assessment of Undiscovered Conventionally Recoverable Petroleum Resources of the Northwest European Region
}

\author{
By Charles D. Masters' and H. Douglas Klemme ${ }^{2}$
}

\begin{abstract}
The estimates of undiscovered conventionally recoverable petroleum resources in the northwest European region at probability levels of 95 percent, 5 percent, statistical mean, and mode are for oil (in billions of barrels): 9, 34, 20, and 15; and for gas (in trillions of cubic feet): $92,258,167$, and 162 .

The occurrence of petroleum can be accounted for in two distinct geological plays located in the various subbasins of the region. Play $I$ is associated with the distribution of mature source rocks of Late Jurassic age relative to four distinct trapping conditions. The play has been demonstrated productive mostly in the Viking and Central Grabens of the North Sea, where the shale has been buried to optimum depths for the generation of both oil and gas. To the north of $62^{\circ} \mathrm{N}$. latitude up to the Barents Sea, source rocks become increasingly deeply buried and are interpreted to be dominantly gas prone; a narrow band of potentially oil-prone shales tracks most of the coast of Norway, but water depths in favorable localities commonly range from 600 to 1,200 feet. To the south of the Central Graben, the Jurassic source rocks are either immature or minimally productive because of a change in facies. Undrilled traps remain within the favorable source-rock area, and exploration will continue to challenge the boundaries of conventional wisdom, especially on the Norwegian side where little has been reported on the geology of the adjoining Bergen High or Horda Basin, though, reportedly, the Jurassic source rocks are missing on the high and are immature in the southern part of the basin.
\end{abstract}

Play II is associated with the distribution of a coal facies of Carboniferous age that is mature for the generation of gas and locally underlies favorable reservoir and sealing rocks. The play is limited largely by facies development to the present area of discovery and production but is limited as well to the southeast into onshore Netherlands and Germany by the unfavorable economics of an increasing nitrogen content in the gas. This increase is apparently caused by excessive temperatures associated with increasing depth of burial of the source rock.

U.S. Geological Survey

'Weeks Exploration Company
The history of discovery in the North Sea would appear to deny the commonly held maxim that large fields are found first and early in the exploration process. However, if the discovery data are examined from the perspective of the award date of each exploration license, then it is clear that the largest fields and most of the reserves have indeed been found early in the exploration process of a particular license. Discoveries made within 1 year of granting the license are on average large giants, and they account for slightly less than two-thirds of the original reserves. Discoveries made within 2 to 5 years of the granting of the license are on average less than giant size and smaller than increment-1-year discoveries by a factor of 4 ; these fields account for a little less than one-third of the reserves. Those fields found 6 or more years after the granting of the license are relatively small and account for 20 percent of all discoveries but only 4 percent of total original reserves. These data suggest that a measure of an area's exploration maturity is the length of time elapsed since the award of the concession.

\section{INTRODUCTION}

Investigation of the petroleum resource potential of the northwest European region was performed under contract to Weeks Exploration Company (Contract No. 4-08-001-17919) by Dr. H. Douglas Klemme. Sources of data include Petroconsultants S.A. and published literature. The intent of this report is to provide a geologic setting for the assessment and to describe our working concept of the reasons for the oil occurrence and factors we believe will be responsible for additional discoveries, as well as those we believe will limit them. The petroleum geology of the North Sea region is well reported in many publications by private and government sources alike; among these, notable compilations and regional syntheses 
by Ziegler (1980), Woodland (1975), Illing and Hobson (1981), and Hallam (1980) provided most of the basic data and interpretation leading to this assessment report. An unpublished interpretation of the geology by $\mathrm{H}$. Douglas Klemme has been only slightly modified for suitability to publication format in displaying the geologic features responsible for the petroleum occurrences.

The resource assessment was conducted by the Resource Appraisal Group (RAG) of the USGS, Branch of Oil and Gas Resources, following the standard procedures developed since 1974 for domestic petroleum resource analysis. The technique, briefly, requires that a given area is studied with particular attention paid to the geologic factors controlling the occurrence, quality, and quantity of the petroleum resource. Standardization of critical elements of the investigations is achieved by the preparation of data forms for each basin, which call for specific volumetric, areal, and rockquality measurements, as well as the determination of basin analogs for comparison purposes. In addition, finding-rate histories and projections are constructed, when possible. From these data and analyses, various analytical techniques are used to calculate a set of resource numbers.

The assessment process itself is subjective; the results of the geological investigation and of the resource calculations derived from volumetric analog comparisons, finding-rate projections, and other techniques of resource calculation are presented to a team of USGS assessment specialists who make their personal estimates conditional upon recoverable resources being present. Initial assessments are made for each of the assessed provinces as follows:

(a) A low resource estimate corresponding to a 95 percent probability of more than that amount; this estimate is the 95th fractile $\left(\mathrm{F}_{95}\right)$;

(b) A high resource estimate corresponding to a 5 percent probability of more than that amount; this estimate is the 5 th fractile $\left(\mathrm{F}_{5}\right)$;

(c) A modal ("most likely") estimate of the quantity of resource associated with the greatest likelihood of occurrence.

The individual estimates are then posted and averaged, and the results debated from the perspective of the personal experiences of the individual assessors; a second and third iteration of the procedure may follow, depending on consensus.
The results of the final estimates are averaged, and those numbers are fitted to a log-normal distribution and further computer processed by using probabilistic methodology (Crovelli, 1981) to show graphically the resource values associated with a full range of probabilities and to determine the 95th fractile, the 5 th fractile, the mode, and the mean, as well as other statistical parameters.

All assessments are made conditional upon the occurrence of commercial petroleum in the assessment region, but the probability of that occurrence differs between regions. To aggregate various assessment regions, varying probabilities of commercial petroleum occurrence must be allowed for by adjusting the assessments in accordance with the marginal probability of the occurrence, thereby producing an unconditional (sometimes referred to as "risked") probability distribution. If commercial petroleum is known, the marginal probability is 1 , and the conditional and unconditional probability distributions are identical. If, however, no commercial petroleum has been heretofore discovered in the region, the marginal probability (a fraction of 1) of that occurrence is estimated subjectively, and the conditional probability distribution is adjusted downward (reflecting the marginal probability limit) to an unconditional probability distribution. Aggregated assessments reflect the adjustments derived from marginal probability and are unconditional.

\section{ACKNOWLEDGMENTS}

The resource assessment for this report was prepared in collaboration with the Resource Appraisal Group of the Branch of Oil and Gas Resources.

\section{REGIONAL GEOLOGY}

The northwest European region of this report (fig. 1) is a mostly submerged part of the western European continental margin bounded and traversed by tectonic elements of widely varying ages, which are largely responsible for the petroleum geology as we can interpret it today. The region includes the Northwest European Basin as well as the Atlantic Shelf basins (Ziegler, 1980 ), the latter of which occur generally to the west of the British Isles and to the northwest of 


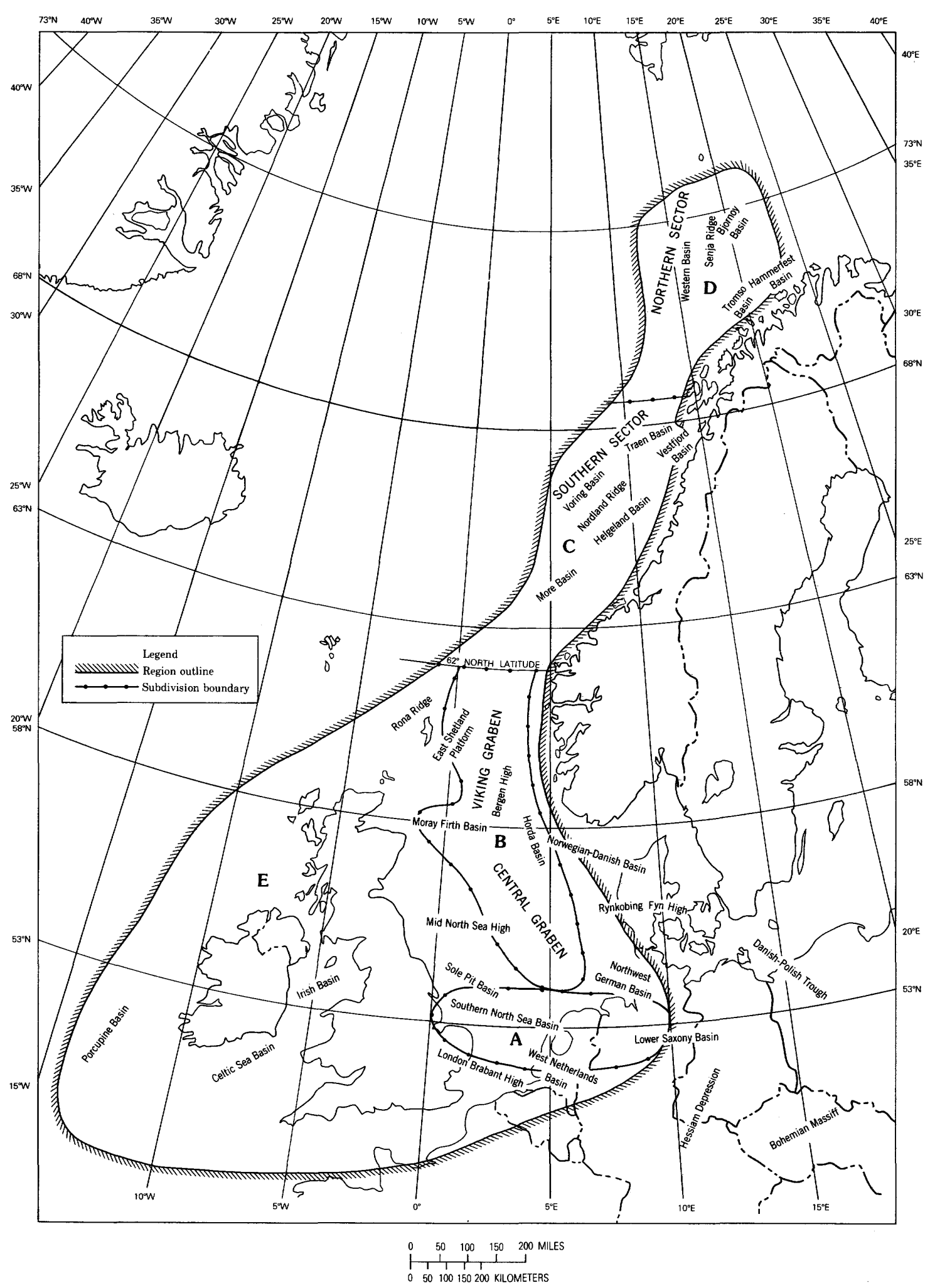

FIGURE 1.-Northwest European assessment region, including the North Sea. 
Norway north of about $62^{\circ} \mathrm{N}$. latitude. To the west and northwest lies the Atlantic Ocean Basin; to the east is the Precambrian craton of the Baltic Shield; and to the south the bounding element is the Variscan metamorphic belt now partly covered by younger sediments (Ziegler, 1981). The geologic history and processes involved in the evolution of this region are complex and highly varied and have resulted in many different locales for the occurrence of petroleum, but in only a few areas did all of the factors necessary to that occurrence come together in an optimum manner so as to result in economically significant deposits. The principal areas in the region with respect to reserves, as well as undiscovered resources, are the Viking and Central Grabens and the Southern North Sea Basin (fig. 1). The Atlantic Shelf basins, which lie generally to the west of the United Kingdom and of Norway, north of $62^{\circ} \mathrm{N}$. latitude, are characterized by somewhat different geology and do not presently have commercial occurrences of petroleum, but their potential for undiscovered resources must be recognized.

Sedimentary rocks of interest span the entire Phanerozoic (fig. 2), but the principal source-rock ages are Carboniferous and Jurassic; reservoirrock ages vary somewhat, but Permian and Jurassic rocks dominate with significant contributions from the rocks of Cretaceous and Tertiary age.

Early Paleozoic platform shelf carbonates and shales ringed the main craton elements of the Canadian and Baltic Shields. The collision of the shields and associated rocks in Middle Silurian produced the Caledonide orogeny and a metamorphic mountain belt extending mainly up the western side of Great Britain, across Scotland and the North Sea, and along the coastal regions of Norway. Caledonide tectonism also occurred locally in various parts of central Europe, but in the Baltic Sea region Caledonide tectonism did not prevail, and unmetamorphosed lower Paleozoic sediments provide targets for petroleum exploration.

A postorogenic period of tensional basin development south of the Caledonides and west of the Baltic Shield occurred in Devonian time. Clastic nonmarine sediments of the Old Red Sandstone Formation were eroded from the Caledonide highlands and deposited into an adjoining subsiding basin that was open to the ocean to the south. The ocean waters, into which shallow-marine platform deposits, typical of the rest of southern Europe at that time, were deposited, extended locally into the Southern North Sea Basin (Ziegler, 1980).
In Carboniferous time, the southern seaway and associated geosynclinal development were displaced by Variscan tectonic activity that metamorphosed and uplifted central Europe and produced a concomitant downwarp across the southern North Sea area through the Netherlands, Germany, and into Poland. Lower Carboniferous sediments were fed into a deep seaway (culm flysch facies), but with continuing uplift and erosion, the increased sedimentation filled the seaway, and eventually a balance of sedimentation and subsidence produced a long-lived, paralic depositional environment. Up to $3,500 \mathrm{~m}$ of coal facies rock (intra-Westphalian age), which provides the source for the gas in this area, were deposited in the southern North Sea area.

Variscan orogeny culminated in pre-Permian time with overthrusting in the south, but compression continued to subtly affect the foreland and produced the Mid North Sea High and adjoining basin downwarps to the north and to the south (fig. 1). Aeolian sediments of the Rotliegendes (eventually to become the reservoir rock for the southern North Sea gas) accumulated predominantly in the Southern Permian Basin (south of the Mid North Sea High, fig. 1); time-equivalent nonmarine muds, conglomerates, and some evaporites were deposited elsewhere in the Southern Permian Basin and in the lesser subsiding Northern Permian Basin (Ziegler, 1980).

Marine depositional conditions returned to the area in Late Permian time owing to continued basin subsidence in excess of deposition and presumably also to an extensional opening to the Zechstein Sea via the Arctic region. Evaporite deposition (rocks which later were to provide a seal for the gas deposits) ensued throughout the northwestern European region, except on the basin margins where freshwater influxes lowered salinity sufficiently to permit carbonate bank and reef growth locally. These reefs are productive exploration targets in onshore Netherlands and Germany.

Nonmarine depositional conditions, owing to broad area uplift, accompanied the onset of rifting in Triassic time; this rifting led eventually to the tectonic opening of the Atlantic seaway. Thick sedimentary sections of red beds and conglomerates developed in the newly formed graben basins and in the continually subsiding Permian basins; the widespread basal Bunter sandstone provides a reservoir in some areas. The rift systems having a general north-south orientation bisected the early east-west Variscan lineaments and resulted in an 


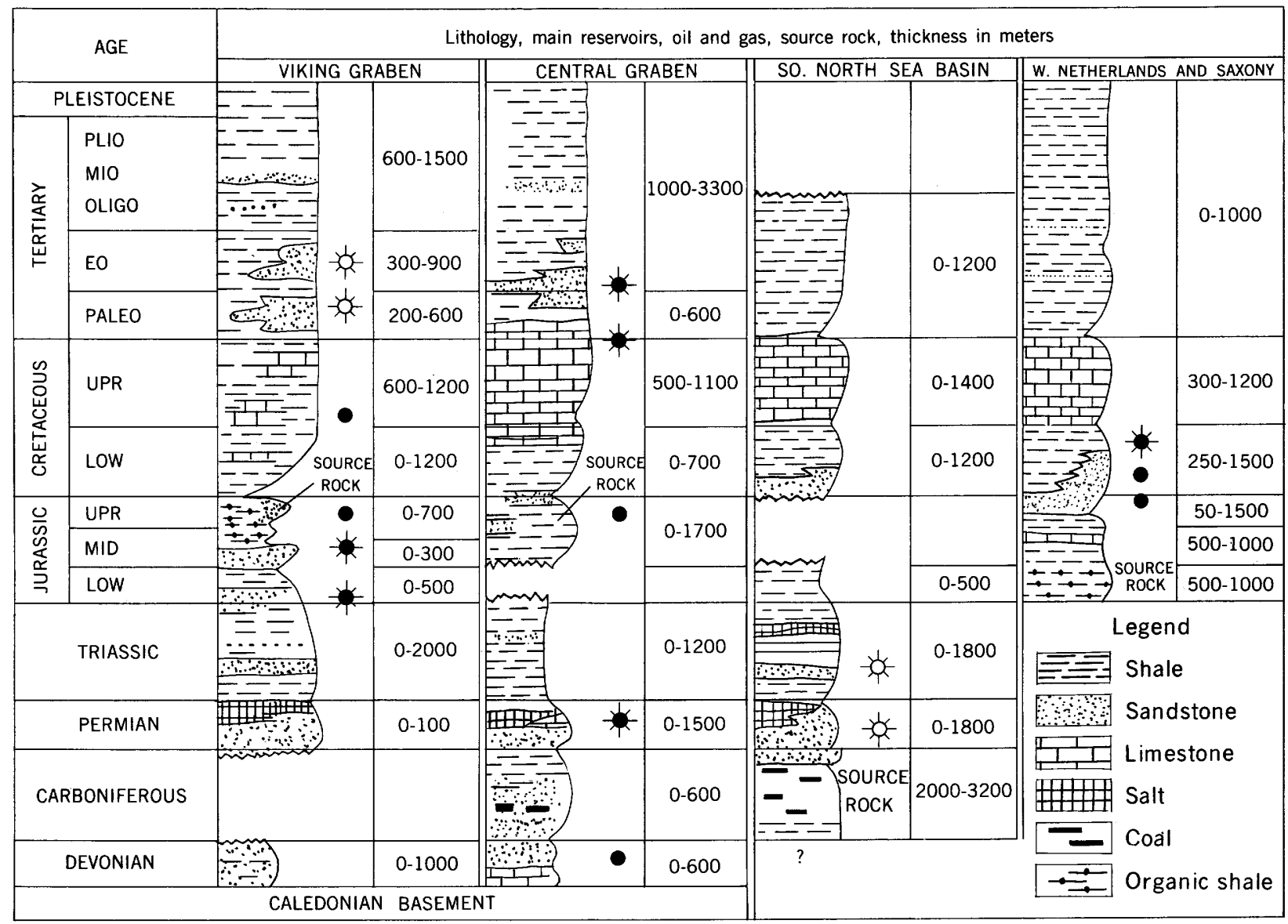

Modified from Ziegler, P. (1980)

FIGURE 2.-Stratigraphic diagrams of selected petroleum provinces.

early access to southern seaways (Tethyan) and later (in Jurassic time) to Arctic seas. One arm of the rift development followed the Variscan basin development to the southeast through Germany and Poland. Seawater influx along this rift extended only into the Southern North Sea Basin and resulted in the deposition, distally, of evaporites (Rot formation) and, in the open seaways, Muschelkalk carbonates. Triassic time closed with a regression to the south and accompanied deposition of the dominantly red-colored, generally finegrained, and somewhat evaporitic Keuper series. The Triassic rocks have minimal petroleum reservoir potential and no source-rock potential; their presence, however, affects burial depths to underlying source rocks in the Carboniferous of the Southern North Sea Basin.

The generally widespread phenomenon of rifting in Triassic time was consolidated in Early Jurassic time into two long, sinuous rift zones, each over
1,000 km long: the Viking and Central Grabens, and the Danish-Polish Trough. North of $62^{\circ} \mathrm{N}$. latitude, the rift zone grades into the Atlantic rift system, and hence the northern Norway coastal region becomes part of an open-ocean, pull-apart system that worldwide is not as favorable an environment for petroleum occurrence as is the twosided rift basin (Klemme, 1981). Marine waters from both the north and the south had access to the region through the rift basins.

Tectonic events throughout the Jurassic continued to activate faulting in these zones and affected depositional environments and types and localities of clastic availability. Statfjord sands, for example, were deposited in association with an Early Jurassic tectonic event. Also in Early Jurassic, a bituminous source-rock facies that supplied petroleum to the overlying Jurassic-Cretaceous reservoir developed in the Southern North Sea Basin area; time-equivalent sediments, however, in 
the central and northern grabens, as well as in eastern Germany and Poland, are not of sourcerock quality. In Middle Jurassic, a volcanic doming in the central North Sea produced a triple junction between the Viking, Central, and Moray Firth (Witchground) Grabens; erosion from this central high fed reservoir sands mostly northward into the Brent area, with a lesser amount being shed to the south. Subsidence in the Late Jurassic followed the doming episode and resulted in deep-water, restricted depositional conditions in the Viking, Central, and Moray Firth Grabens, as well as in selected parts of the Norwegian Atlantic Shelf north of $62^{\circ} \mathrm{N}$. latitude. These conditions produced the Kimmeridgian "hot shale" source rock; marginally, the Sole Pit and Norwegian-Danish Basin areas subsided less rapidly, and depositional environments were such as to produce a different nonsource-rock facies. In the most southerly part of the Central Graben area, the hot-shale facies changes to the nonsource-rock Weald facies, and likewise farther to the south into the Netherlands and Germany and to the southeast into eastern Germany and Poland, a nonsource-rock facies also obtains. The general transgression of the seas in the Late Jurassic produced shoreline sand deposits marginal to the Moray Firth and to the west side of the Viking Graben; some of these sands were swept out to the rift edge and tumbled into the deep-water slope and ocean-basin environment. Both the shelf and deep-ocean sandstones are potential reservoir rocks.

By Cretaceous time, the North Sea region was no longer significantly affected by Atlantic rifting action. Continued subsidence associated with general transgression produced a carbonate/shale depositional system; the pure chalks that accumulated suggest the remoteness of positive tectonic elements capable of supplying clastic materials. Late Cretaceous, Alpine compressional stresses affected the general northwest European basin system in such a way as to produce continued downwarping in some areas but inversions in others; the uplifted blocks remained positive throughout the subsequent Cenozoic. Cenozoic sedimentation was concentrated in Mesozoic depocenters and served to further bury the underlying rocks; thus the Mesozoic source rocks were subjected to their maximum depths of burial and maturity levels. Only in the vicinity of the East Shetland Platform did early Cenozoic delta development and deep-water sand deposition, similar to still earlier Jurassic processes, produce reservoir rocks of significance to the occurrence of petroleum.

\section{PETROLEUM GEOLOGY}

Possibly never before in the history of petroleum exploration has a major basin been developed so systematically by utilizing at every stage state-ofthe-art exploration and development tools. Key to the development, also, has been the extraordinary public availability of data that permitted a rapid evolution of the collective thinking and led to the present extant petroleum geology synthesis.

Two distinct geologic situations are responsible for almost all of the oil and gas in the North Sea region. The first, and most prolific of the two, is the dominantly Mesozoic oil and gas play (Play I) in the Viking, Central, and Moray Firth Grabens, in the small basins south and southwest of Ireland (figs. 3 and 4), and in the basins north of $62^{\circ} \mathrm{N}$. latitude (figs. 5, 6, 7 and 8). The second is the Paleozoic gas play (Play II) in the Southern North Sea Basin and in the Irish Basin (figs. 1 and 9).

Play I. - The Mesozoic play is closely controlled by the distribution of the Upper Jurassic, Kimmeridgian source shale, which is in turn controlled by the geometry and location of the grabens (figs. $3,4,5$, and 7). South of the Mid North Sea High in the Central Graben, facies changes destroy the source-rock character of the Jurassic, and depth of burial is such as to limit maturity. Likewise, in the Horda Basin and in the Norwegian-Danish Basin, chances for good Jurassic source rock development appear limited. Farther to the southeast in the Danish-Polish Trough and outside of the assessment area, Upper Jurassic rocks have clearly changed facies so as to be less suitable for source rock. To the southwest of the main North Sea graben development, Upper Jurassic rocks appear to vary from suitable to nonsuitable facies but commonly are not buried deeply enough for maturation (fig. 4). We assume that the Lower Jurassic rocks, which provide a source for modest oil generation in part of northwest Europe and, as well, some pockets of Kimmeridgian "hot shales" (fig. 2), are also present in the rifted portions of the English Channel Basin, the Celtic Sea Basin, and in the Porcupine Basin (fig. 1). Though the possible presence of Kimmeridgian source rock is encouraging, we have little evidence to suggest that petroleum occurrences should be different from 


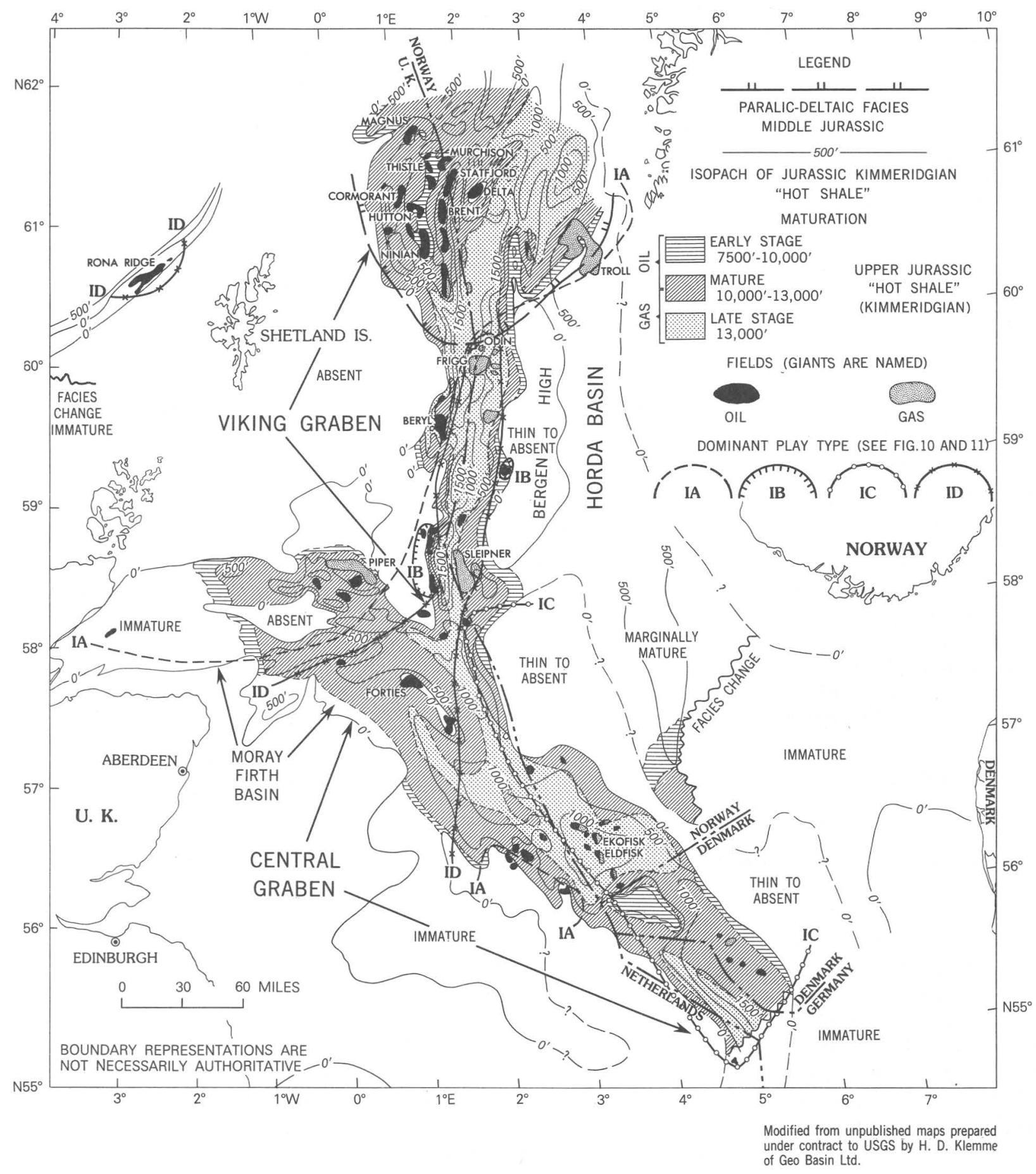

Figure 3.-Play I, central North Sea region. Shows the location of potential petroleum basins between latitudes $55^{\circ} \mathrm{N}$. and $62^{\circ} \mathrm{N}$., isopach distribution of Jurassic Kimmeridgian source rock, interpretation of source-rock maturity, location of associated oil and gas fields, and the distribution of dominant play types as described in fig. 10. 


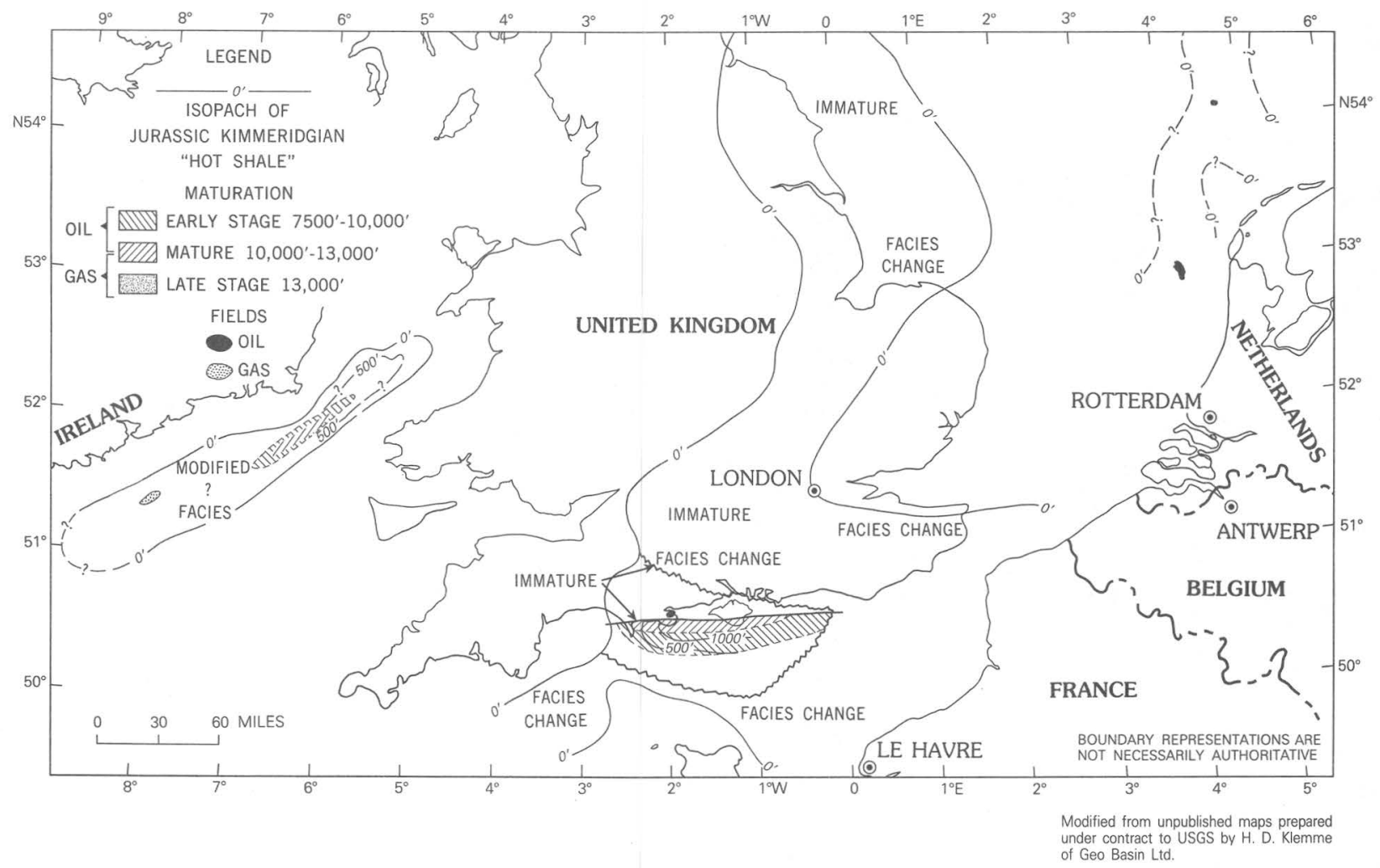

FIGURE 4.-Play I, southern and southwest North Sea region. Shows the location of potential petroleum basins between latitudes $49^{\circ} \mathrm{N}$. and $54^{\circ} \mathrm{N}$., isopach distribution of Jurassic Kimmeridgian source rock, interpretation of source-rock maturity, and location of associated oil and gas fields.

those discovered elsewhere in northwest Europe but outside of the North Sea proper; we assume therefore only modest potential. A further area of significant interest is the Rona Ridge west of the Shetland Islands (fig. 3). A giant, heavy-oil field has been discovered, which, owing to oil type and minimal present-day depth of burial, may never be economically recovered. Its occurrence, however, does indicate a pocket of Late Jurassic source-rock maturity that would not be predicted, necessarily, by this analysis. Even though we think we have embraced the principal controlling elements of the petroleum geology, surprises, both. positive and negative, will continue to intervene.

North of $62^{\circ} \mathrm{N}$. latitude, data are much more limited, but, by using the southern area as a model, it is possible, with configurations derived from published CDP seismic, to infer the distribution of geologic units in the northern area (figs. 5, 6,7 , and 8). Clearly, graben development was not regionally continuous, and good source-rock conditions may not be ubiquitous. Even if Jurassic (Kimmeridgian) source rock is present, the depth of burial, over a large portion of the area, suggests that gas will be dominant. Discoveries by the initial wells in the Tromso Basin (fig. 7) and in the Helgeland Basin (fig. 5), which have favorable twosided rift configurations, have been gas and condensate. To date, developmental drilling has not proved the occurrence of a supergiant, the field size that likely will be necessary to proceed with development; the source rock, however, has been proved, and good opportunities for structural traps are present in both basins (figs. 5 and 7). The Bjornoy Basin north of Tromso likely has some mature Jurassic source rock (figs. 7 and 8), but water depth is in excess of $1,200 \mathrm{ft}$ and trapping conditions are unknown. The Western Basin, west and northwest of Tromso, likewise lies in water depths in excess of $1,200 \mathrm{ft}$, and the presence or absence of favorable Jurassic source rocks is unknown (figs. 7 and 8).

The petroleum in the Mesozoic play is found in four different types of traps (fig. 10) and is reservoired in rocks of several different ages (fig. 2). The geographic clustering of trap types in the basin 
clearly shows trap relationship to certain tectonic and stratigraphic conditions (fig. 3). We have no evidence of significant lateral migration of oil; in this assessment we assume only minimal lateral oil migration and, hence, a geographical proximity between the traps and the areas of oil generation.

Play II.-The Paleozoic play, dominantly in the Southern North Sea Basin, is closely constrained by the geographic distribution of the necessary juxtaposition of the source rock, the reservoir rock, and the seal (fig. 9). All of those, including the related sedimentary rocks, are delimited in turn by the geometry of the Caledonide and Variscan events. The source rocks are the Westphalian coal measures, the major reservoir rock is the Rotliegendes aeolian sandstone, and the seal is provided by the regionally distributed Zechstein salts. Locally, in the Irish Basin, the Zechstein seal is not present. Gas leaked up into Triassic sands that were in turn sealed by local Triassic evaporites and produced the giant Morecambe gas field; the basin is small, however, and we do not expect other such surprises. To the east into onshore Netherlands and Germany, most of the critical geologic factors remain positive. However, with respect to depth of burial, and hence temperature, of the Westphalian coal source rocks, they experience an increase such that resultant nitrogen generation reduces the heating quality of the gas to an even greater degree than in Groningen; as a result, the gas is economically unacceptable. The complexly block-faulted traps are typical across the area, and the field-size distribution is generally expectable (fig. 11). Groningen, however, is so large, as compared to the next largest Leman field, that statistically one might expect the existence of fields of intermediate sizes, but the density of drilling is such as to give reason to argue strongly against this possibility.

Barents Sea -Though not a part of this assessment area, the Barents Sea basins, east and northeast of Bjornoy and Tromso, would appear to present mostly a lower Paleozoic play (figs. 7 and 8), unless it can be demonstrated that, in fact, Jurassic or some other age of rock is in proper facies and suitably buried for maturation. Though little is known of the Paleozoic section, we do not anticipate favorable Devonian source rock as found in the Volga Urals section of the USSR; rather, we would anticipate an Old Red Sandstone facies similar to that in the North Sea and on Spitzbergen (Ulmishek, 1982).
Exploration maturity:-By standards of other large producing areas, the northwest European region has not been tested by a large number of exploratory wells; still it is possible to argue that the exploration has been very thorough, and most areas south of $62^{\circ} \mathrm{N}$. latitude are in an advanced stage of exploration. This is so not only because of the technical competence of the explorationists but also because economic conditions are such that only relatively large fields are presently economic. To date, approximately 2,000 exploratory wells have been drilled in the North Sea region and, in our judgment, most of the important blocks, particularly in the United Kingdom, have been tested by one or more wells. Because we can infer certain geologic conditions that limit the favorable area, we would contend that an advanced stage of exploration and development has been achieved in every area except offshore Norway, but we would suggest that water depth and absence of infrastructure, especially north of $62^{\circ} \mathrm{N}$. latitude, will significantly hamper future development.

The discovery history of the well-explored region would appear to support this interpretation. Commonly in a new region, we expect the large fields to be discovered early in the exploration process, primarily because they are geographically large. In the North Sea, however, large discoveries are distributed throughout the exploration history (fig. 12), with the largest yet, the Troll gas field, found in Norwegian waters in 1978, rivaling the giant gas field at Groningen, which was the cause of all of the North Sea excitement about 20 years ago. This unique discovery pattern is true in this region only because of the systematic exploration plan controlled by governmental, area-specific licensing. When one examines the discovery history in relation to the year of the award of the concession, one finds that the fields discovered within the first year after the award account for 64 percent of the reserves discovered and an average field size several times larger than those fields discovered after greater time lapses since the concession award. Those fields found several years after the concession award account for only a small percent of total discovered reserves and are notably smaller. These data suggest that discovery patterns are comparable to other regions and that most of the North Sea region is in a mature stage of exploration, at least with respect to the extant exploration concepts. 


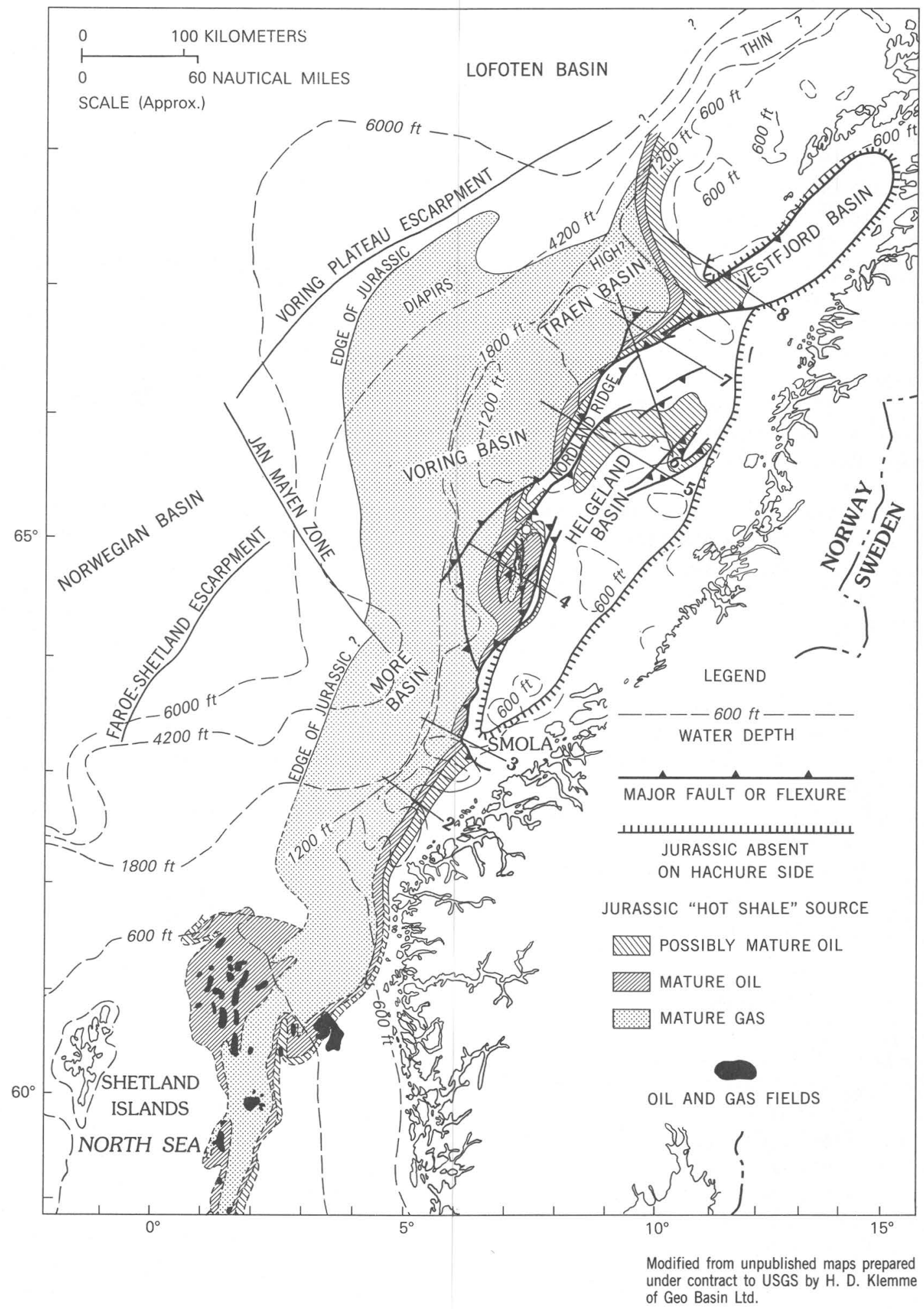

FIGURE 5.-Potential petroleum basins, distribution of Jurassic Kimmeridgian source rocks in the North Sea between latitudes $59^{\circ} \mathrm{N}$. and $69^{\circ} \mathrm{N}$., inferred degree of maturity of source rock, and oil and gas fields. Section lines refer to interpreted seismic sections of fig. 6. 

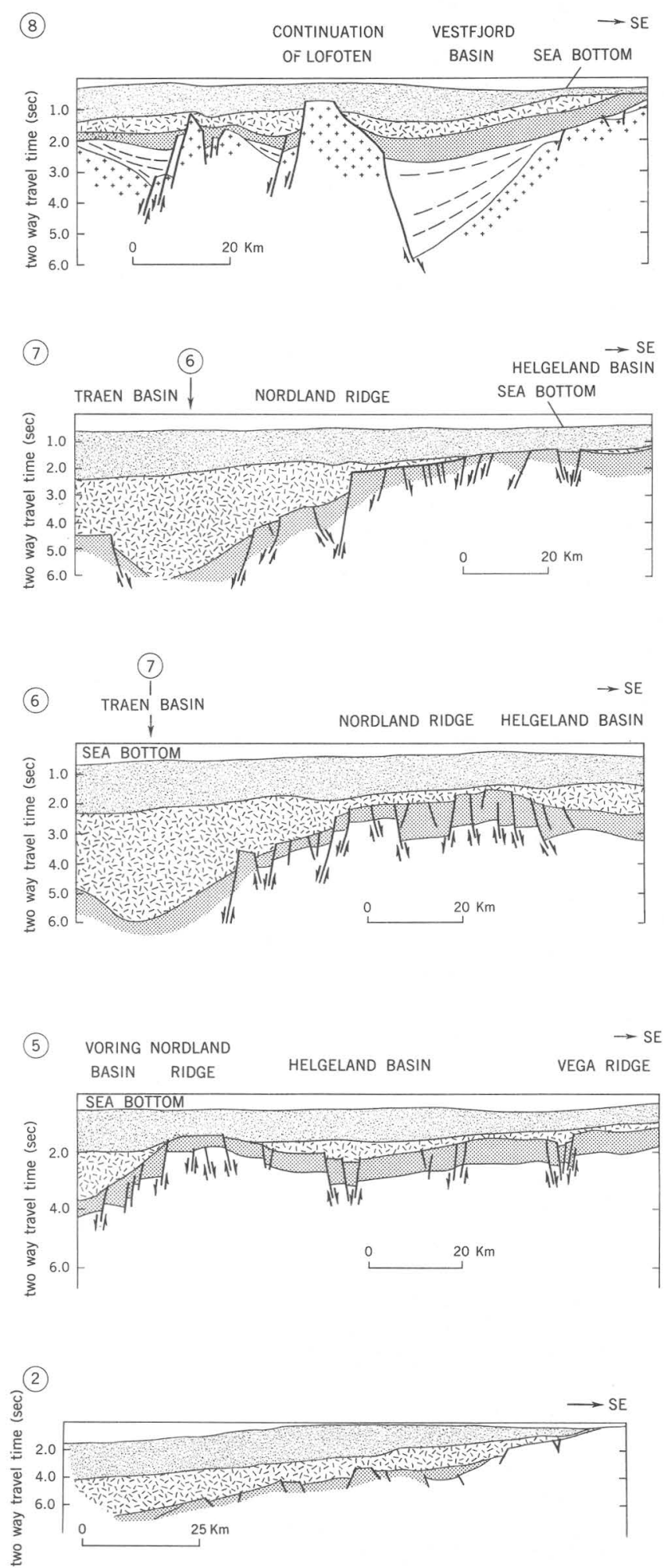
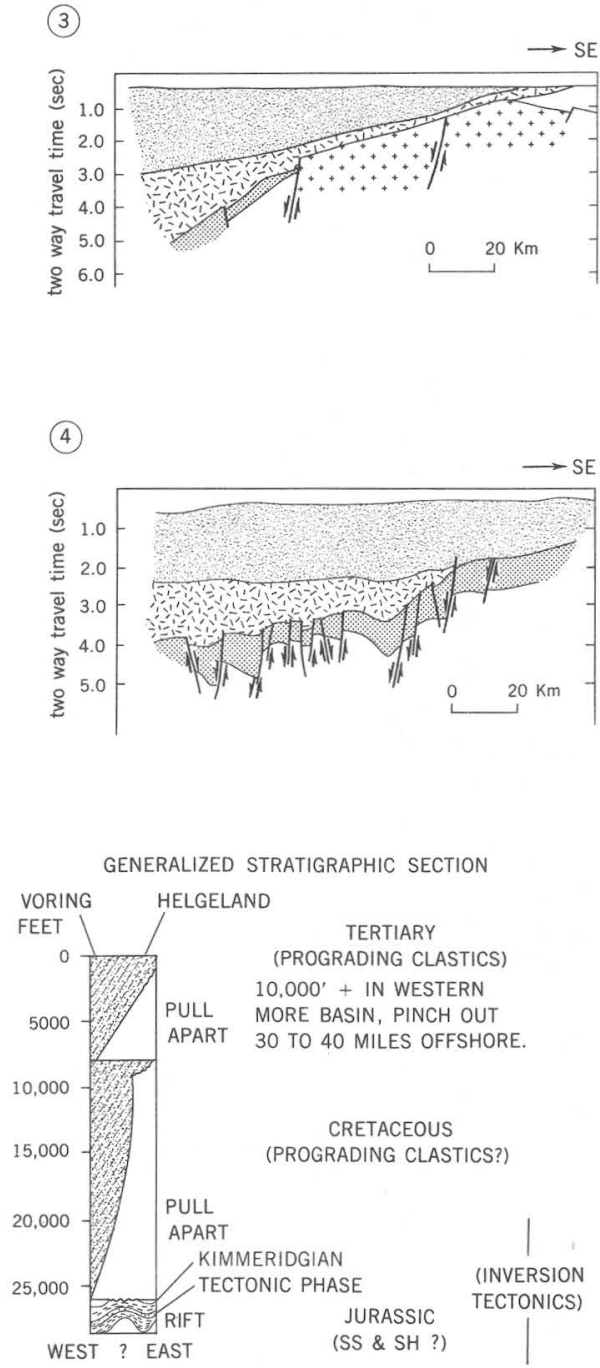

LEGEND
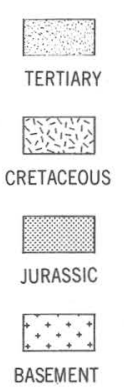

Modified from Jorgensen and Navrestad, 1981

FIGURE 6.-Interpreted seismic stratigraphy and structure. Locations of sections shown on fig. 5. Modified from Jorgensen and Navrestad, 1981. 


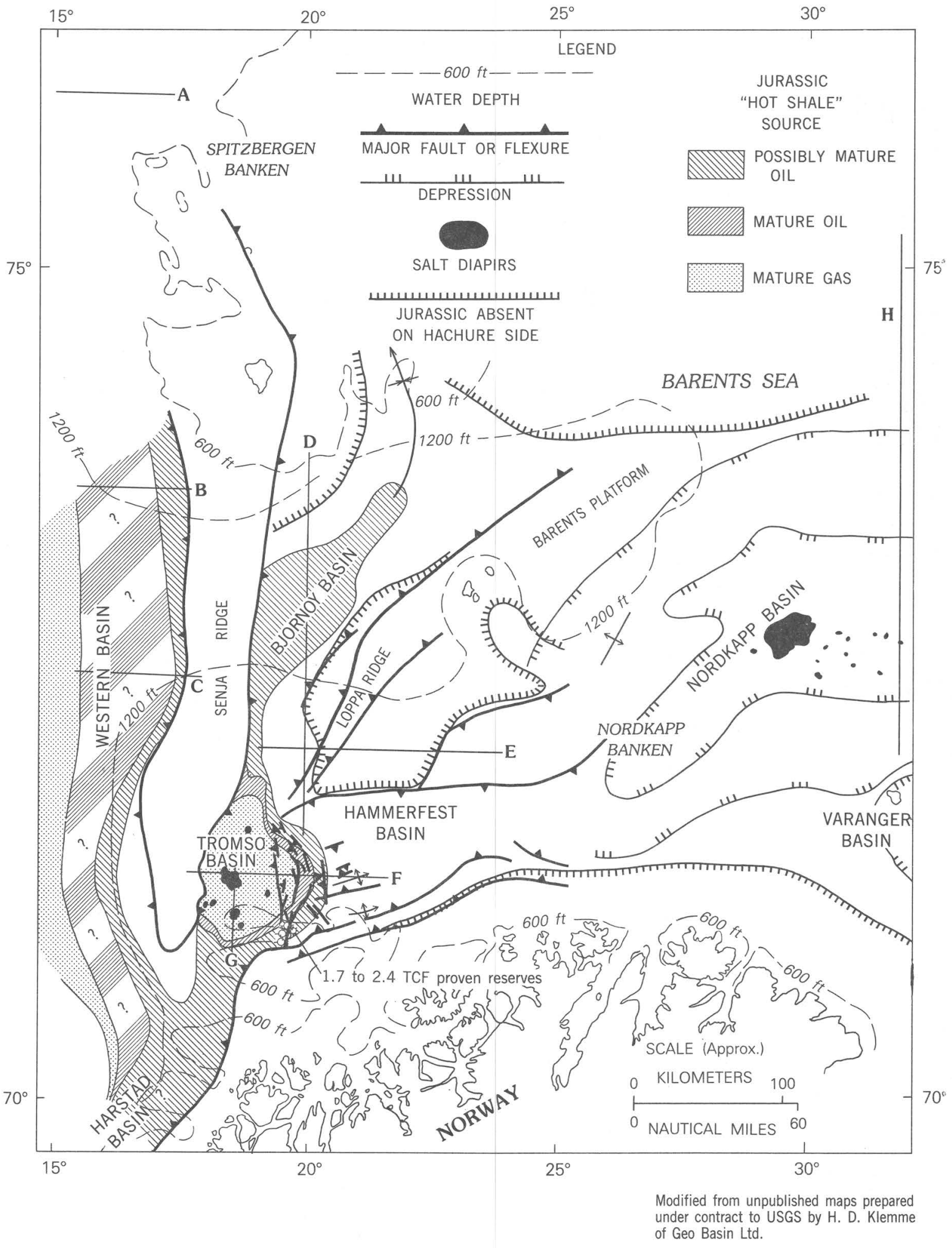

FIGURE 7.-Potential petroleum basins, distribution of Jurassic Kimmeridgian source rock in the North Sea between latitudes $69^{\circ} \mathrm{N}$. and $76^{\circ} \mathrm{N}$., as well as inferred degrees of maturity of source rock. Section lines refer to interpreted seismic sections on fig. 8 . 

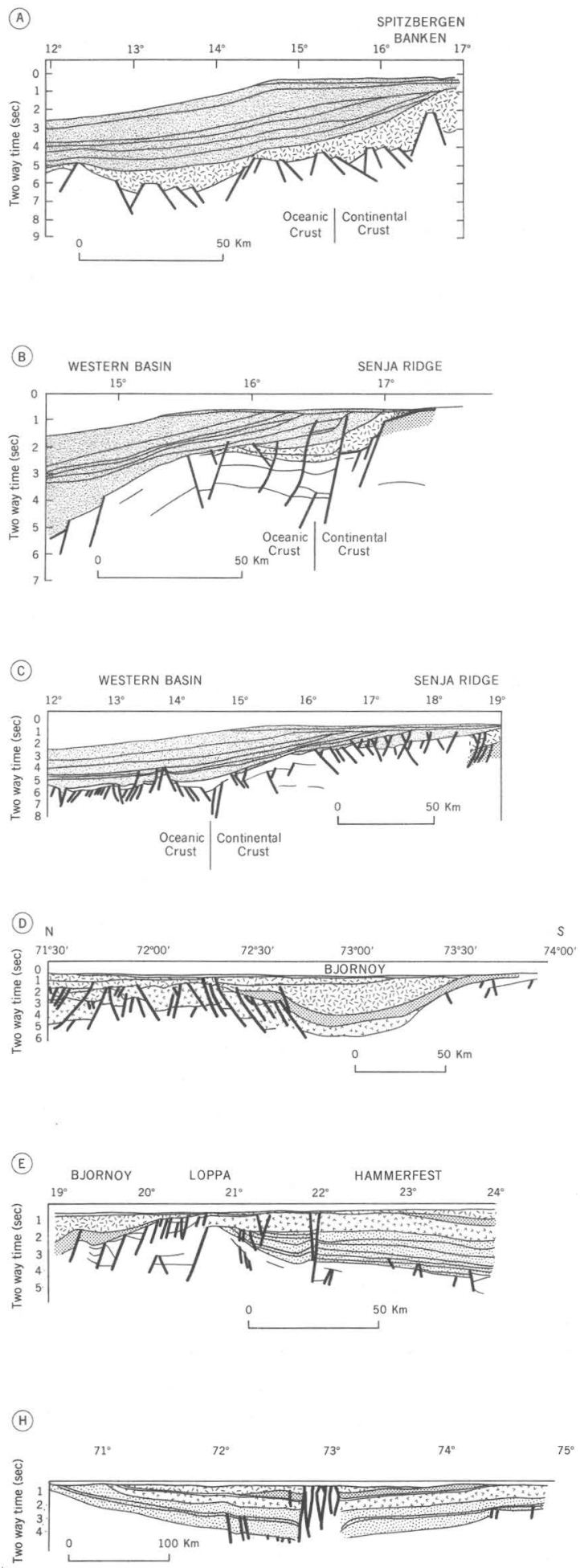

(F)

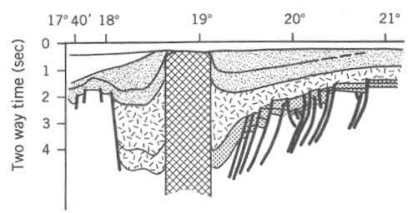

(G)

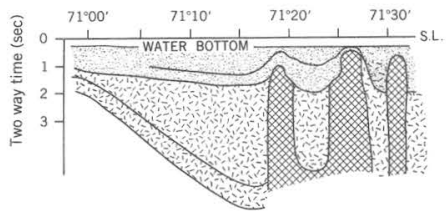

$$
\begin{aligned}
& \text { LEGEND } \\
& \text { TERTIARY } \\
& \text { CRETACEOUS } \\
& \text { PALEOZOIC } \\
& \text { SALT }
\end{aligned}
$$

GENERALIZED STRATIGRAPHIC SECTION

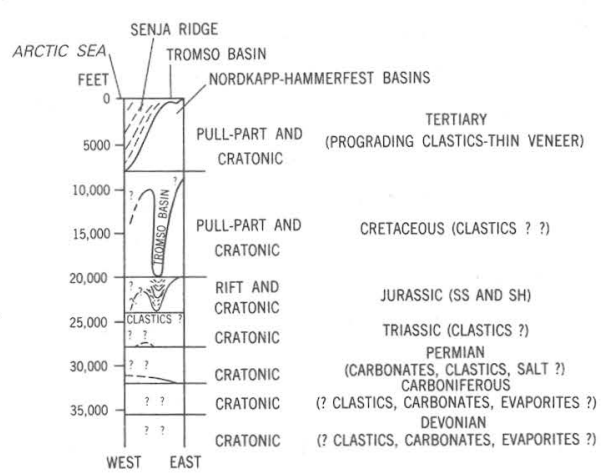

A-E and $\mathrm{H}$ modified from Ronnevik, 1981

FIGURE 8.-Interpreted seismic stratigraphy and structure. Locations of sections shown on fig. 7. Modified from Ronnevik, 1981. 


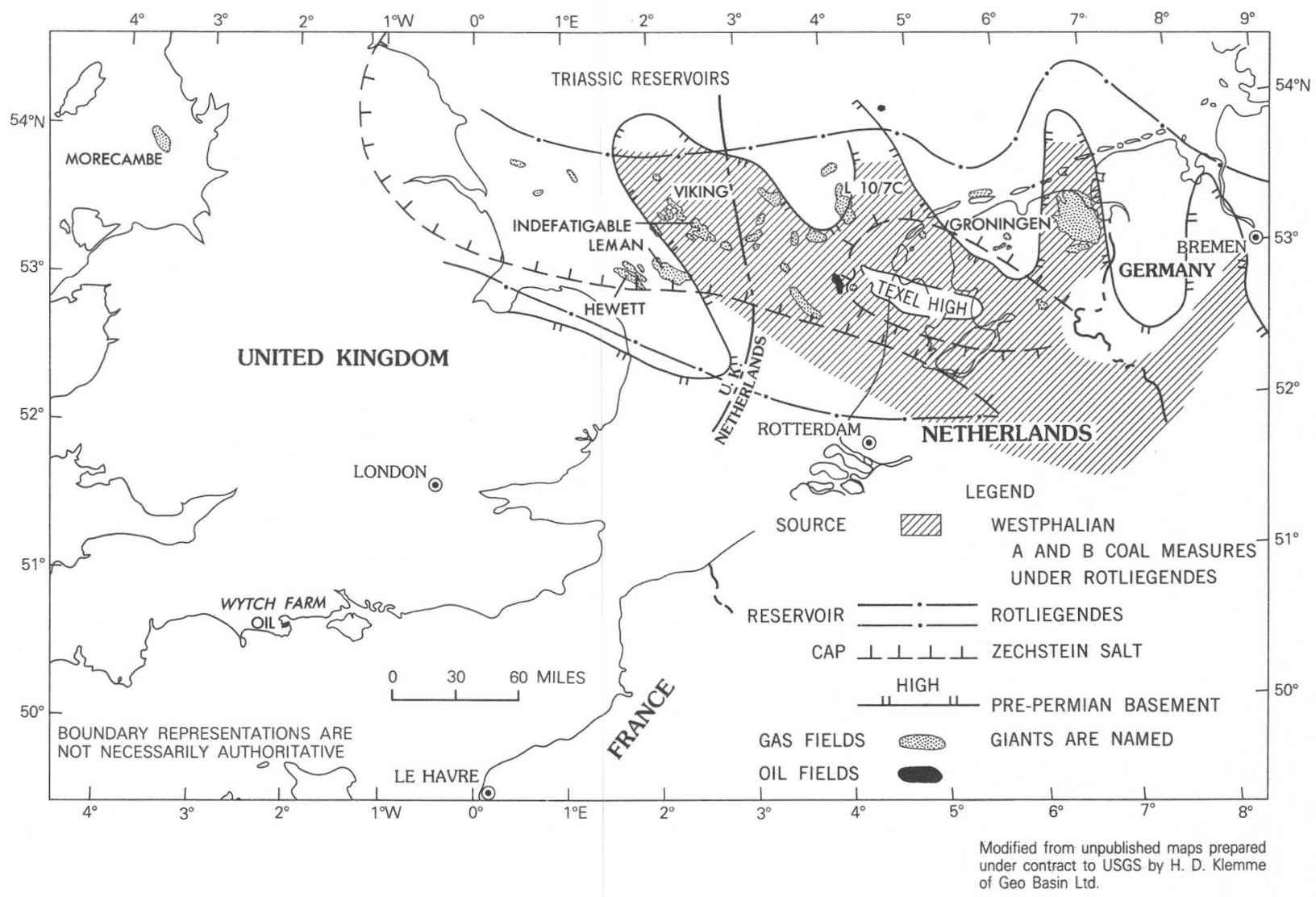

Figure 9.-Play II, southern North Sea region. Shows potential petroleum basins between latitudes $50^{\circ} \mathrm{N}$. and $54^{\circ} \mathrm{N}$., the distribution of principal source, reservoir, and sealing facies, and the distribution of oil and gas fields.

\section{RESOURCE ASSESSMENT}

The location of the northwest European assessment region is shown in figure 1 . Estimates by the U.S. Geological Survey of oil and gas resources in this region are given in table 1 and figures 13 through 26. These probabilistic distributions of the assessment are arranged to first show the aggregate amounts assessed for the entire northwest European region, followed by aggregates of the area north of $62^{\circ} \mathrm{N}$. latitude and the area south of $62^{\circ}$ N. latitude, and finally showing the assessments for individual play areas. Supplementary data of interest in analyzing these estimates are supplied in table 2 .

At the time of the assessment, the country-bycountry allocation of resources was estimated on the basis of play distribution by country and on the proportion of total estimated resources assigned to each play (table 3). This estimate was considered to be an allocation of the mean quantity of resources, and a curve was fitted by using the mean estimate to determine the resource values associated with a full range of probabilities for each country. From this, we calculated and selected for reporting a 95 percent to 5 percent probability range, a mode, and a statistical mean. The numbers are reported to several significant figures, which represent only the precision of the arithmetic process, not the accuracy of the assessment.

In utilizing these numbers, the reader should be aware that no single number represents the estimate; rather, we are saying that there is a 90 percent probability that the correct value lies between the 95 percent and 5 percent reported values. The mean is singled out only as a convenient measure of central tendency that can be added arithmetically to other mean values. The mean value actually represents the assessment only at a single probability value; the measure of central tendency that expresses the greatest range of probability values, and hence the most satisfactory single number expression of the assessment, is the mode. If the distribution of the values of an assessment were 
normal, the mean and the mode would be equal; in fact the distribution of the estimate tends toward $\log$ normal. This tendency produces an asymmetry in the distribution that causes the mean values, which in effect represent the center of gravity of the estimate, to move out toward the higher estimated values and the lower probabilities. This difference between the mean and the mode in a lognormally distributed estimate is especially prominent in estimation situations that have significant unknowns. In such situations, the tendency has been to allow for favorable conditions at the low probability, which shifts the center of gravity of the assessment, or the mean, to a greater degree than would be expectable in an assessment under conditions of greater geologic certainty.

Because the use of resource estimates involves dealing with the unknown, we believe it prudent for the analyst to consider the reality of any point on the curve and to actively consider a range of probability values. Commonly, we can assume that if the low probability assessment proves accurate, we are better off than planned and may have delayed only temporarily an investment opportunity. If the high probability assessment, however, proves accurate and we have gambled on the mean or mode, or even on other less-probable high values, the decisions deriving therefrom may prove to be calamitous.

The analyst should recognize that if he is considering a single frontier basin with a marginal probability of less than 1 , he may want to consider the conditional assessment while taking note of the marginal probability (one element of risk) of there being any commercial petroleum at all.

Resource categories assessed-Based on the assumption that present economic and technologic conditions will continue, the assessment of undiscovered conventionally recoverable petroleum resources includes those resources that can be extracted by using conventional methods (Dolton, and others, 1981). The assessment does not include inferred resources that may yet be found in new pay zones or in extensions of existing fields. Also excluded from the assessment, even if present, are unconventional resources such as extra-heavy oil deposits, tar deposits, oil shales, as well as gas in low permeability (tight) reservoirs, gas occluded in coal, gas in geopressured reservoirs and brines, and natural gas hydrates.
TABLE 1.-Assessment of undiscovered conventionally recoverable petroleum resources of the northwest European assessment region

[Resource assessment by USGS as of July 20, 1982; see also figs. 13 through 26]

\begin{tabular}{|c|c|c|c|c|c|c|c|}
\hline \multicolumn{4}{|c|}{ Crude oil, in billions of barrels ${ }^{1}$} & \multicolumn{4}{|c|}{ Natural gas, in trillions of cubic feet ${ }^{1}$} \\
\hline $\begin{array}{l}\text { Low } \\
\mathrm{F}_{95}{ }^{2}\end{array}$ & $\begin{array}{c}\text { High } \\
\mathrm{F}_{5}\end{array}$ & Mean & Mode & $\begin{array}{l}\text { Low } \\
F_{95}\end{array}$ & $\begin{array}{c}\text { High } \\
F_{5}\end{array}$ & Mean & Mode \\
\hline 9 & 34 & 20 & $\begin{array}{c}15 \\
\text { (Fig. 13) }\end{array}$ & 92 & 258 & 167 & $\begin{array}{c}162 \\
\text { (Fig. 14) }\end{array}$ \\
\hline
\end{tabular}

\footnotetext{
${ }^{1}$ For gas, billions of barrels of oil equivalent (BBOE) @ 6,000 $\mathrm{ft}^{3} / \mathrm{bbl}=27$; oil plus gas modal value $B B O E=42$.

${ }^{2} F_{95}$ denotes the 95 th fractile; the probability of more than the amount $F_{95}$ is 95 percent. $F_{5}$ is defined similarly.
}

TABLE 2.-Supplemental and comparative data relative to the resource assessment of the northwest European assessment region ${ }^{1}$

[A * indicates quantity positive but data not available ]

\begin{tabular}{|c|c|c|}
\hline & $\begin{array}{l}\text { Crude oil, } \\
\text { in billions of } \\
\text { barrels }\end{array}$ & $\begin{array}{l}\text { Natural gas, } \\
\text { in trillions of } \\
\text { cubic feet }\end{array}$ \\
\hline \multicolumn{3}{|l|}{ Cumulative production to Dec. } \\
\hline \multicolumn{3}{|l|}{ Identified reserves to Jan. 1 , } \\
\hline Demonstrated ---------- & 23.6 & 222 \\
\hline Inferred -------------- & $*$ & * \\
\hline \multicolumn{3}{|l|}{ Undiscovered recoverable resources } \\
\hline (mode) -- & 15 & 162 \\
\hline Total $^{3}$ & 42.4 & 424 \\
\hline
\end{tabular}

${ }^{1}$ Cumulative production and reserves are composited estimates from various sources.

${ }^{2}$ Following terminology outlined in USGS Circular 860. "Demonstrated" is equivalent to API "Proved and Indicated Additional." (For natural gas, "indicated additional" is zero.) "Inferred" represents anticipated field growth in existing fields.

${ }^{3}$ Original recoverable resources (ultimate); $\mathrm{BBOE}$ for gas $=72$; total oil and gas (mode) $=114$ BBOE.

\section{COMMENTS}

- The dominant analog used in volumetric calculations was the Klemme type 3 rift basin (Klemme, 1981). Some basins to the west of the British Isles and to the northwest of Norway north of $62^{\circ} \mathrm{N}$. latitude did not possess the two-sided rift characteristic and were classified as Klemme type 5 pull-apart basins (see text for discussion). 
PLAY I

UPPER JURASSIC (KIMMERIDGIAN)

"HOT SHALE" FACIES SOURCE

Showing field size and play type
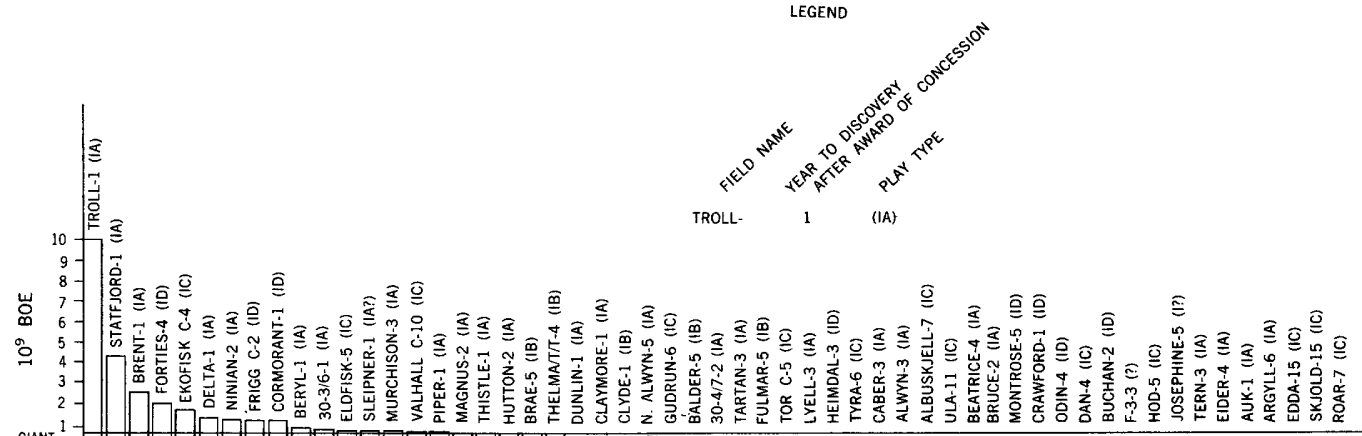

\section{GIANT 0 a}

PLAY TYPE IA

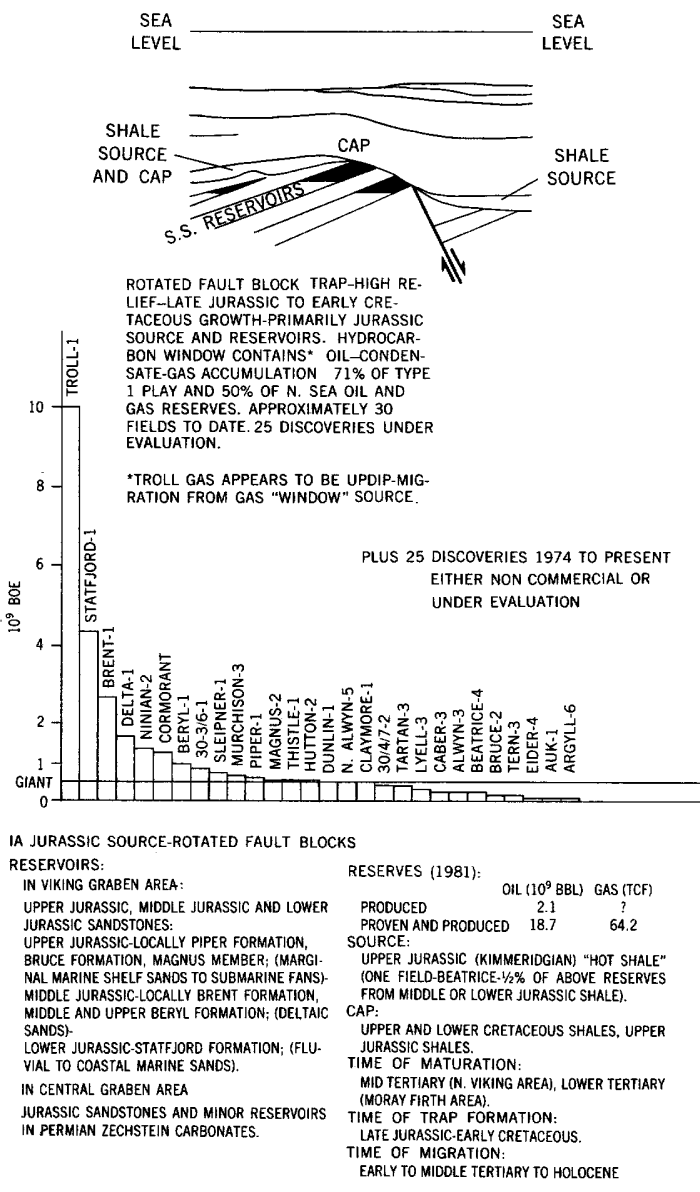

JURASSIC SOURCE (GENERAL) RESERVOIRS:

DEVONIAN, TRIASSIC, JURASSIC, CRETACEOUS,

PALEOCENE AND EOCENE IMAINLY JURASSIC AND LOWER TERTIARY)

RESERVES (1981): OIL-(10 $0^{9}$ BBL) GAS TCF

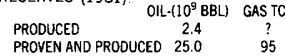
PROVEN

OURCE: CURRENT EVIOENCE INDICATES THE MAJOR SOURCE IS FROM UPPER JURASSIC (KIMMERID GIAN] "HOT RADIOACTIVE BITUMINOUS SHALE JURASSIC SHALES BELOW (KIMMERIOGIAN). CAP: SHALE ANO IMPERVIOUS CARBONATES, JURASSIC, CRETACEOUS, AND LOWER TERTIARY.
TIME OF MATURATION: LATE CRETACEOUS TO MID-TERTIARY (DEPENDENT
UPON BURIAL RATES)-CONTINUING TO PRESENT. TIME OF TRAP FORMATION:

MAJOR TECTONIC MOVEMENT OUTLINED TRAPS IN LATE JURASSIC TO EARLY CRETACEOUS, SUB SEQUENT LOCAL SALT FLOWAGE AND COMPAC PALEOCENE.
PIONED SOME TRAPS IN POST

TIME OF MIGRATION:

EXPULSION EFFICIENCY:

6\% OVERALL (TO DATE)-

ASSUME: AVERAGE TOC $7.5 \%, 3640$ CUBIC MILES (LOCALLY; $9 \%$ BETWEEN $60^{\circ}$ AND $62^{\circ}, 4 \%$ VIKING GRABEN BETWEEN 5830' AND 60, $4 \%$ CENTRAL GRABEN BETWEEN $55^{\circ}$ AND $58^{\circ} 30^{\prime}$ ).
PLAY TYPE IB

SEA LEVEL. SEA
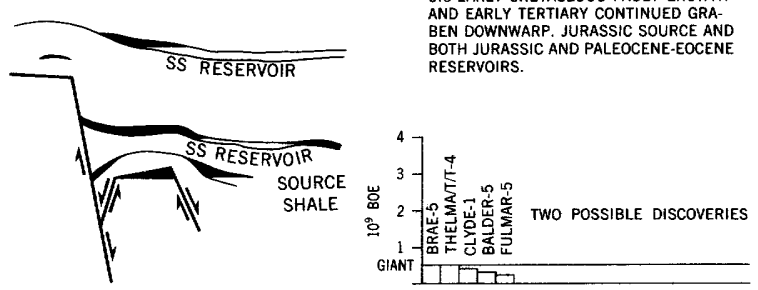

IB JURASSIC SOURCE.FAULT ZONE/STRATIGRAPHIC RESERVOIRS UPPER JURASSIC - LOCALLY BRAE FORMATION 1) JURASSIC RESERVOIRS-LATE JURASSIC-EARLY (SUBMARINE DELTA FAN SAND). 2) PALEOCENE RESERVOIRS-MIODLE TERTIARY PALEOCENE-DISTAL UP.DIP PINCHOUT OF SUBMARINE. DELTA FAN SAND.
RESERVES (1981):
OH ( $\left.10^{\circ} \mathrm{BBL}\right)$ GAS (TCF) TIME OF MIGRATION:
EARLY TERTIARY TO HOLOCENE (CONSIDERABLE STRATIGRAPHIC CONTROL). $\begin{array}{lll}\text { PRODUCED } & -\overline{1} & -\end{array}$ SROVENAN SOURCE: CAP: SHALE AND CLAY.UPPER JURASSIC-LOWER TERTIME OF MATURATION:

EARLY TO MIDDLE TERTIARY

Figure 10.-Listing by size of fields attributed to Play I, further division of the occurrence of petroleum into four different diagrammed trap types, and a listing of fields attributable to each. Certain characteristics of the play and of each trap type are also listed. 
PLAY TYPE IC

SEA

SALT DIAPIR WITH DRAPE, HIGH RELIEF,

PRE-AND POST-PALEOCENE GROWTH.

PRIMARILY JURASSIC SOURCE AND
PALEOCENE RESERVOIR, $11 \%$ OF PLAY

PALEOCENE RESERVOIR, $11 \%$ OF PLAY I
OIL AND GAS RESERVES (BOE). GAS TO

OIL $44 \% / 56 \%$ RATIO
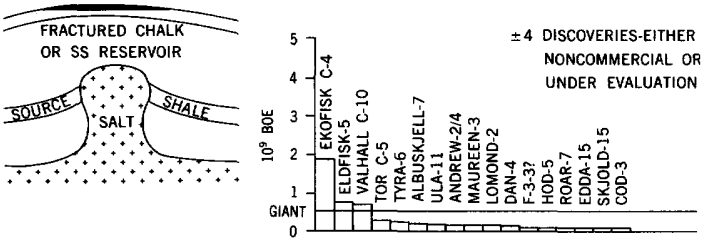

IC JURASSIC SOURCE-DRAPE OVER DIAPIR RESERVOIRS:

PALEOCENEICRETACEOUS-EKOFISK AND TOR FORMATIONS (CHALK) AND MONTROSE GROUP (DEEP-WATER SANDS).

RESERVES (1981):

OIL ( $\left.10^{\circ} \mathrm{BBL}\right)$ GAS (TCF) $\begin{array}{lrc}\text { PRODUCED } & 9 & ? \\ \text { PROVEN AND PRODUCED } & 5.0 & 13.0\end{array}$

MOST PROBABLY UPPER JURASSIC (KIMMERIDGIAN) "HOT SHALE".

CAP: ALUY IMPERVIOUS CHALK

TIME OF MATURATION:

LATE CRETACEOUS (PRESENTLY IN "GAS WINDOW"

TIME OF TRAP FORMATION: POSITION OF PALEOCENE. POST-PALEOCENE

DRAPE.

TIME OF MIGRATION:
LATE CRETACEOUS TO HOLOCENE-PRESENT TRAP

LATE CRETACEOUS TO HOLOCENE-PRESENT TRAP

FIL MDTERTIARY TO RECENT

-

PLAY TYPE ID

SEA SEA.

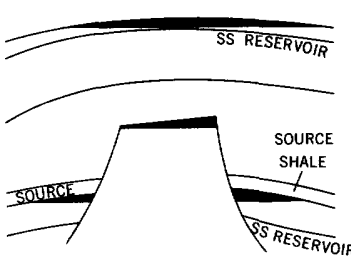
HORST IOFTEN BALD WITH COMPACTION, VARIABLE RELIEF, LATE MESOZOIC GROWTH, TERTIARY COMPACTION AND 9 FIEIDS ( $54 \%$ GAS TO $46 \%$ OII) AND 4 DISCOVERIES UNDER EVALUATION.

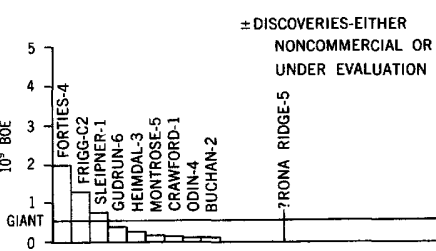

D JURASSIC SOURCE-HORST WITH COMPACTION

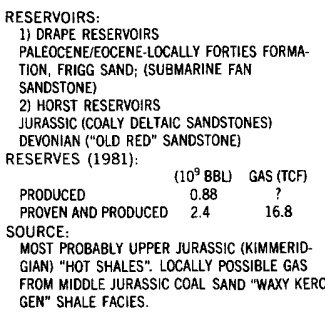

CAP:
CAP:

TIME OF MATURATION.

LATE CRETACEOUS-EARLY TERTIARY TO HOLOCENE (DEPTH DEPENDENT.

TIME OF TRAP FORMATION CRETACEOUS

DRAPE RESERVOIRS-POST-PALEOCENE (LOCAL STRATIGRAPHIC CONTROL).

TIME OF MIGRATION:
MAJOR RESERVES-POST-PALEOCENE
HORST RESERVOIRS-LATE JURASSIC TO LATE
Modified from unpublished maps prepared under contract to USGS by H. O. Klemme of Geo Basin Ltd.

Figure 10.-Continued.

PLAY \|

UPPER CARBONIFEROUS (WESTPHALIAN) COAL SOURCE SEA LEVEL SEA LEVEL
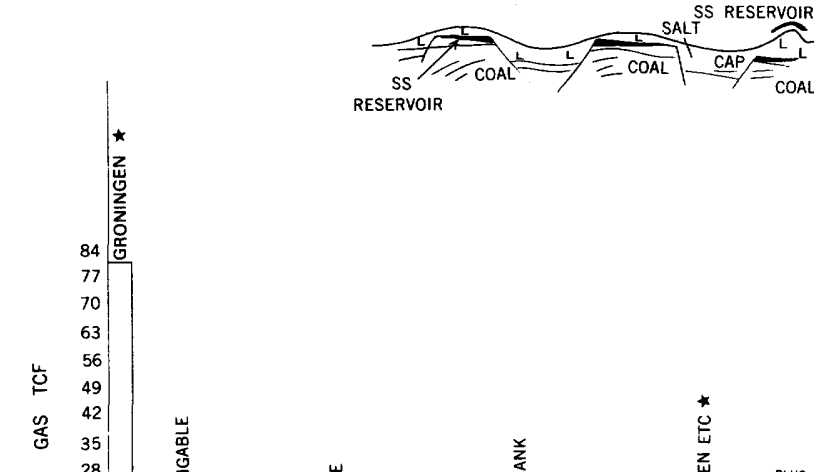

^ ONSHORE
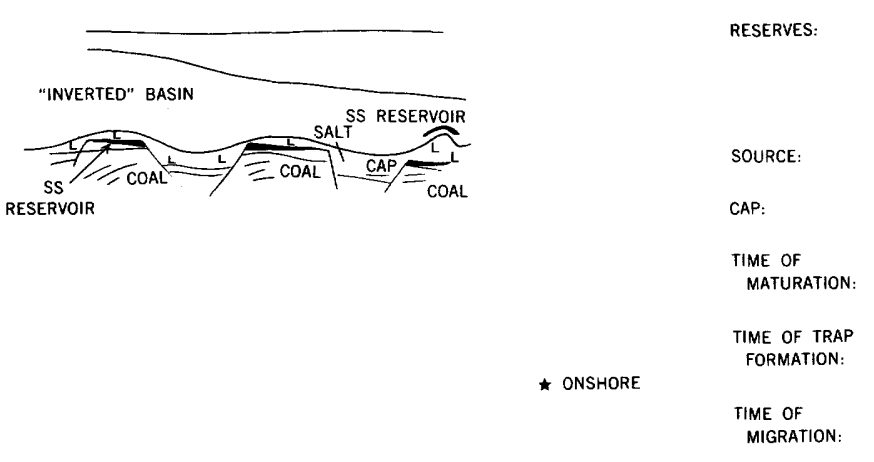

IRISH SEA

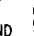

PIUS SHALER ONSHORE AND OFFSHORE FIELDS AND \pm 20 GERMAN ONSHORE FIELOS GIANT 3.5

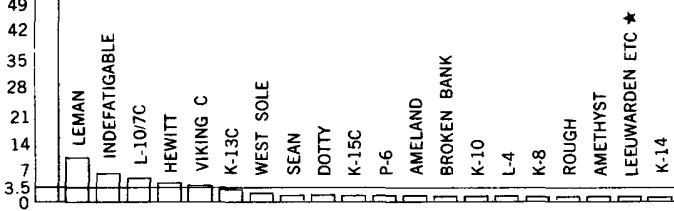

\pm 45 DISCOVERIES (OFFSHORE)

1966 TO PRESENT-EITHER

NON COMMERCIAL OR UNDER

EVALUATION
II CARBONIFEROUS COAL SOURCECOMPLEX, BLOCK-FAULTED TRAPS

RESERVOIR:

PERMIAN-(PRIMARILY) ROTLIEGEND-DUNE AND SABKA SANDS, MINOR) ZECHSTEIN CARBONATES, HAUPTDOLOMITESANDS, (MINOR) ZECHSTEIN CARBONATES, HAUPIDOLOMITEUPPER BUNTER-DESERT SANDSTONES.

$\begin{array}{lcc} & \text { OIL }\left(10^{9} \mathrm{BBL}\right) & \text { GAS (TCF) } \\ \text { PRODUCED } & ? & 40 \\ \text { PROVEN AND PRODUCED } & ? & 145 \\ & & (100 \text { TCF ONSHORE- } \\ & & 45 \text { TCF OFFSHORE) }\end{array}$

CARBONIFEROUS-WESTPHALIAN COAL MEASURES THERMAL METAMORPHISM TO GAS

PERMIAN-(PRIMARILY) ZECHSTEN SALT, TRIASSIC-(MINOR) SALT AND SHALE.

EARLY TO MIDDLE MESOZOIC (LATE CRETACEOUS INTERRUPTION IN INVERTED AREAS).

LATE PALEOZOIC-MESOZOIC (TERTIARY RESHAPING OF TRAPS IN INVERTED AREAS).

MESOZOIC TO PRESENT IINVERTED AREAS TERTIARY REMIGRATION).

Modified from unpublished maps prepared under contract to USGS by H. D. Klemme of Geo Basin LId.

\section{FIGURE 11.--Listing by size of fields attributed to Play II, a generalized diagram of trap type, and a listing of certain characteristics} of the play. 


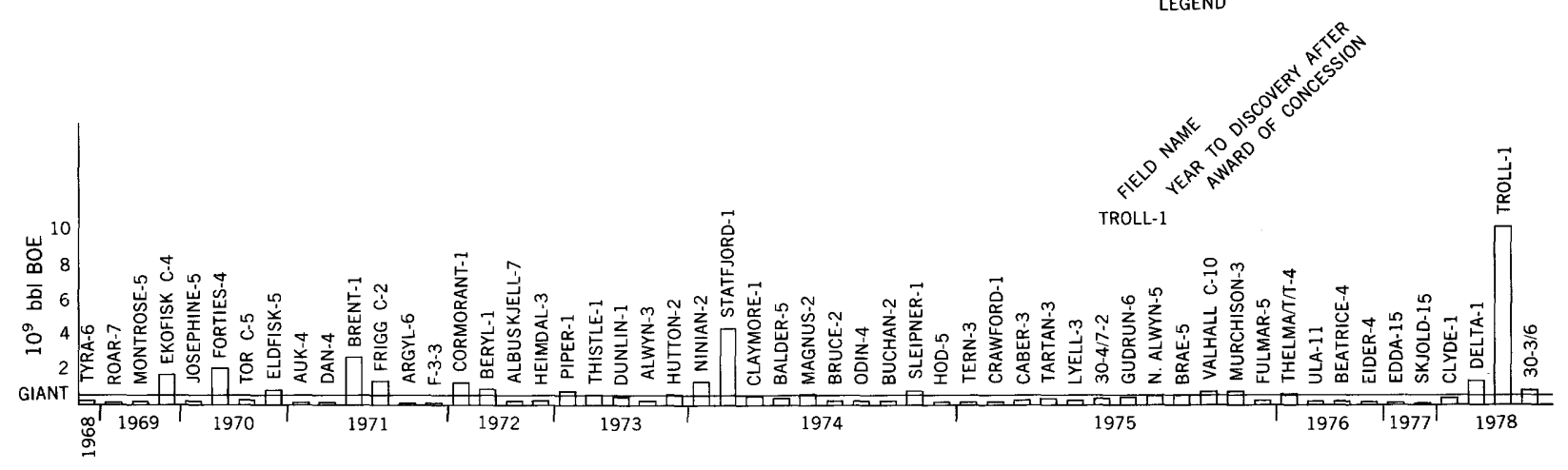

DISCOVERY HISTORY

By field size according to time-lapse increment from year of award of concession

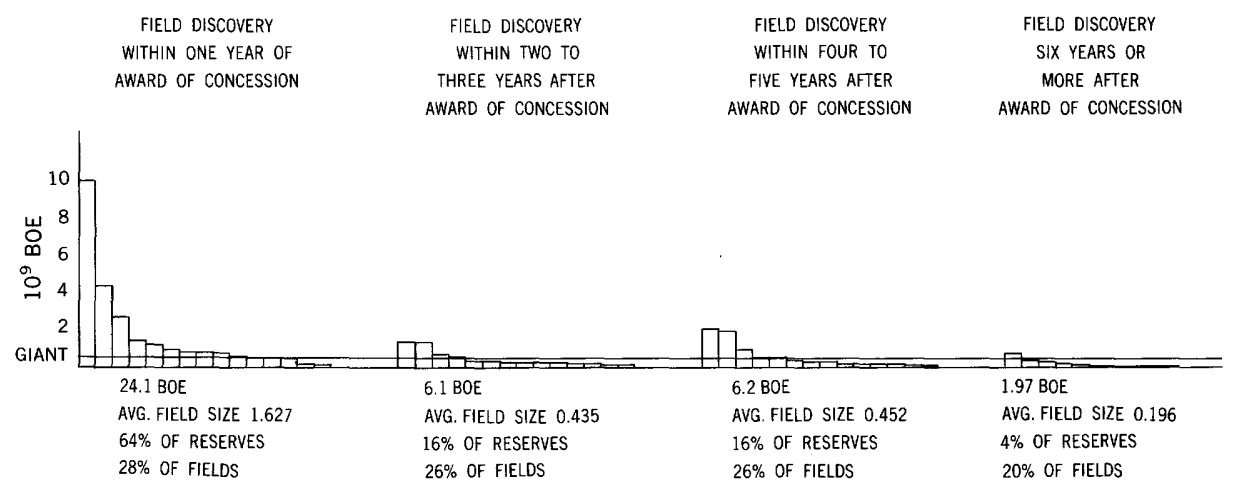

FIGURE 12.-Discovery history by year of discovery and by field size according to time-lapse increment from year of award of concession. Note that discovery history relative to concession date confirms concept of large discoveries coming early in the exploration process.

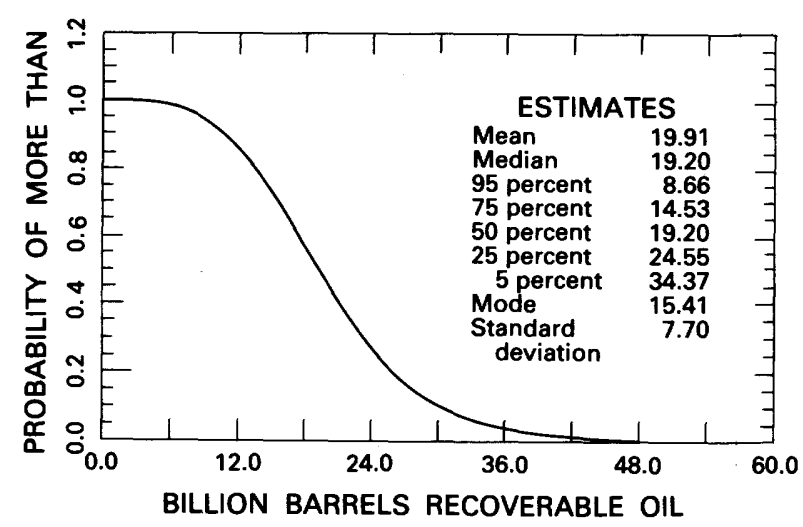

FIGURE 13.-Northwest European region, subregions $\mathrm{A}+\mathrm{B}+\mathrm{C}+\mathrm{C}+\mathrm{E}$, aggregate recoverable oil. (Unconditional assessment; date-7/13/82.)

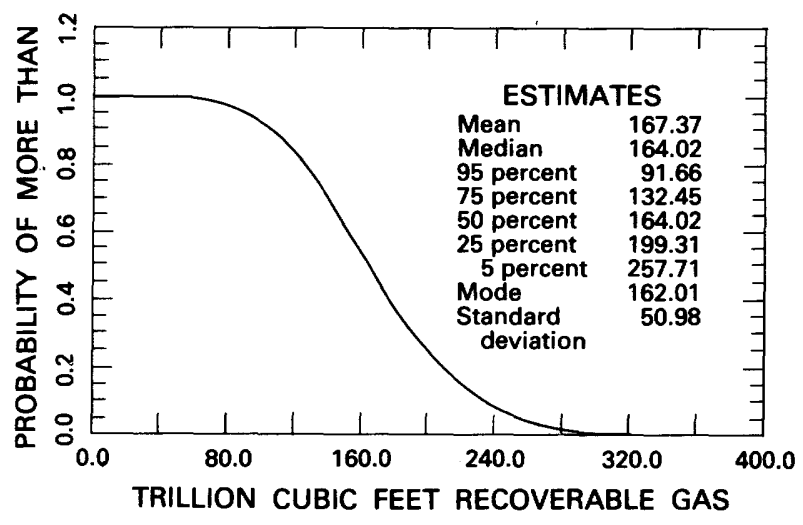

FIGURE 14.-Northwest European region, subregions $A+B+C+D+E$, aggregate recoverable total gas. (Unconditional assessment; date-7/13/82.) 
TABLE 3.-Distribution by country and by subregion of undiscovered recoverable petroleum resources in the northwest European assessment region

\begin{tabular}{|c|c|c|c|c|c|c|}
\hline & \multicolumn{3}{|c|}{ Crude oil (BB) } & \multicolumn{3}{|c|}{ Natural Gas (Tcf) } \\
\hline & Low & High & Mean & Low & High & Mean \\
\hline \multicolumn{7}{|c|}{ South of $62^{\circ} \mathrm{N}$. latitude (assessment date March 10, 1982) } \\
\hline \multicolumn{7}{|l|}{$\begin{array}{l}\text { Viking and Central Grabens, } \\
\text { Moray Firth Basin, and } \\
\text { Ireland area (Play I): }\end{array}$} \\
\hline All countries -------- & 3.7 & 23.2 & 11.9 (fig. 4) & 25.4 & 145.7 & 78.6 (fig. 5 \\
\hline United Kingdom ----- & 0.7 & 4.2 & 2.2 & 2.3 & 13.1 & 7.0 \\
\hline Norway ------------ & 2.8 & 17.6 & 9.0 & 21.6 & 123.8 & 66.8 \\
\hline Denmark ---------- & 0.1 & 0.7 & 0.4 & 0.8 & 4.4 & 2.4 \\
\hline Germany ---------- & $<0.1$ & 0.2 & 0.1 & 0.2 & 1.5 & 0.8 \\
\hline Ireland -- - - ----- & 0.1 & 0.5 & 0.2 & 0.5 & 2.9 & 1.6 \\
\hline \multicolumn{7}{|l|}{$\begin{array}{l}\text { Southern North Sea Basin } \\
\text { and Ireland area (Play II): }\end{array}$} \\
\hline All countries -------- & 0.2 & 2.0 & 0.9 (fig. 6) & 8.4 & 44.1 & 23.8 (fig. 7 \\
\hline United Kingdom ----- & 0.0 & 0.5 & 0.0 & 4.2 & 19.8 & 11.9 \\
\hline Netherlands - & 0.2 & 1.5 & 0.9 & 4.2 & 22.5 & 11.9 \\
\hline Ireland ---------- & 0.0 & 0.0 & 0.0 & 0.0 & 1.8 & 0.0 \\
\hline \multicolumn{7}{|l|}{$\begin{array}{l}\text { Total South of } 62^{\circ} \mathrm{N} \text {. latitude } \\
\text { (Play I and Play II): }\end{array}$} \\
\hline All countries -- & 4.4 & 23.8 & 12.8 (fig. 8) & 47.3 & 174.0 & 102.4 (fig. 9) \\
\hline United Kingdom ----- & 0.8 & 4.3 & 2.3 & 7.6 & 27.8 & 16.4 \\
\hline Norway ----------- & 3.0 & 17.1 & 9.2 & 32.2 & 118.3 & 69.6 \\
\hline Denmark ----- & 0.2 & 0.5 & 0.3 & 0.9 & 3.5 & 2.0 \\
\hline Germany ----------- & $<0.1$ & 0.2 & 0.1 & 0.5 & 1.8 & 1.0 \\
\hline Netherlands -------- & 0.3 & 1.2 & 0.6 & 5.2 & 19.1 & 11.4 \\
\hline Ireland ----------- & 0.1 & 0.5 & 0.3 & 0.9 & 3.5 & 2.0 \\
\hline
\end{tabular}

North of $62^{\circ} \mathrm{N}$. latitude (assessment date July 30,1982 )

Southern sector (More, Helgeland,

$\begin{array}{lllllll}\text { Voring, etc.) --- } & 3.3 \text { (fig. 10) } & 0.0 & 80.2 & 34.0 \text { (fig. 11) }\end{array}$

Northern sector (Tromso,

$\begin{array}{lllllll}\text { Hammerfest, etc.) --_-- } & 0.0 & 10.3 & 3.8 \text { (fig. 12) } & 0.0 & 69.9 & 31.0 \text { (fig. 13) }\end{array}$

Total North of $62^{\circ} \mathrm{N}$. latitude:

Norway ------ $\quad 0.0 \quad 15.7 \quad 7.1$ (fig. 14) $\quad 17.9 \quad 127.6 \quad 65.0$ (fig. 15)

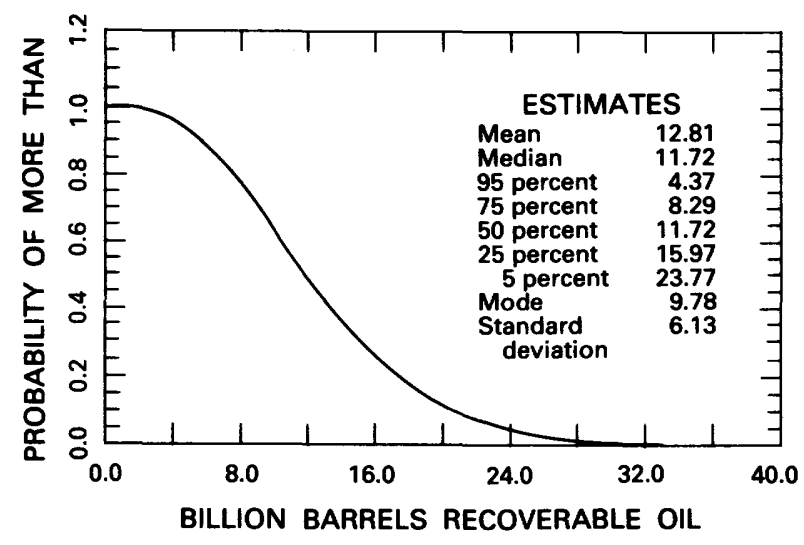

Figure 15.-Northwest European region, south of $62^{\circ} \mathrm{N}$, subregions $A+B+E$, aggregate recoverable oil. (Unconditional assessment; date-7/13/82.)

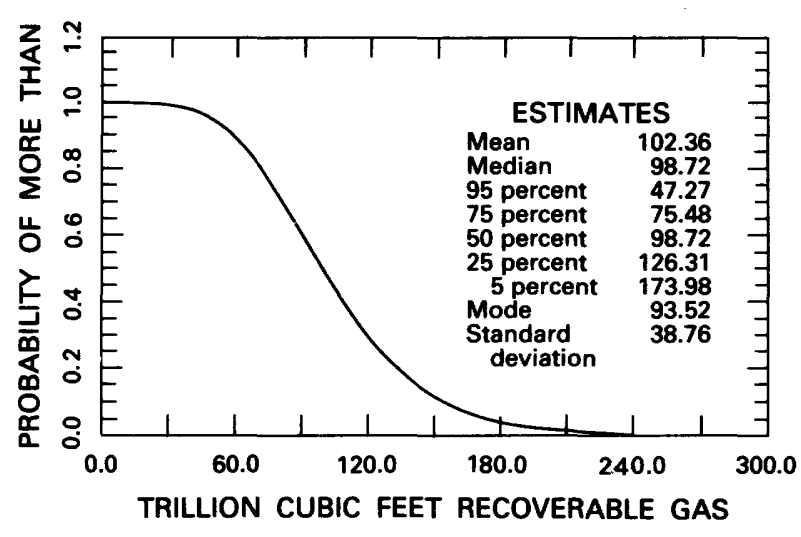

FIgURE 16.-Northwest European region, south of $62^{\circ} \mathrm{N}$., subregions $\mathrm{A}+\mathrm{B}+\mathrm{E}$, aggregate recoverable total gas. (Unconditional assessment; date-7/13/82.) 


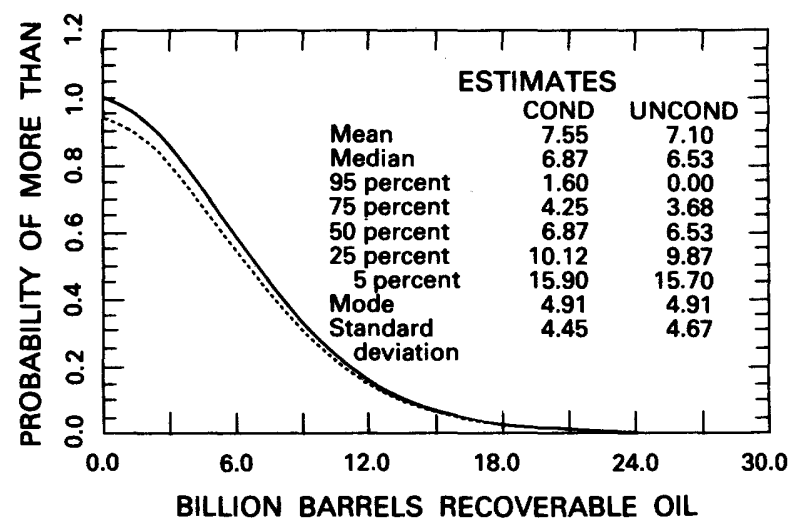

Figure 17.-Northwest European region, north of $62^{\circ} \mathrm{N}$., subregions $\mathrm{C}+\mathrm{D}$, aggregate recoverable oil. (Conditional assessment-solid line; unconditional assessment-dashed line; date-7/13/82.)

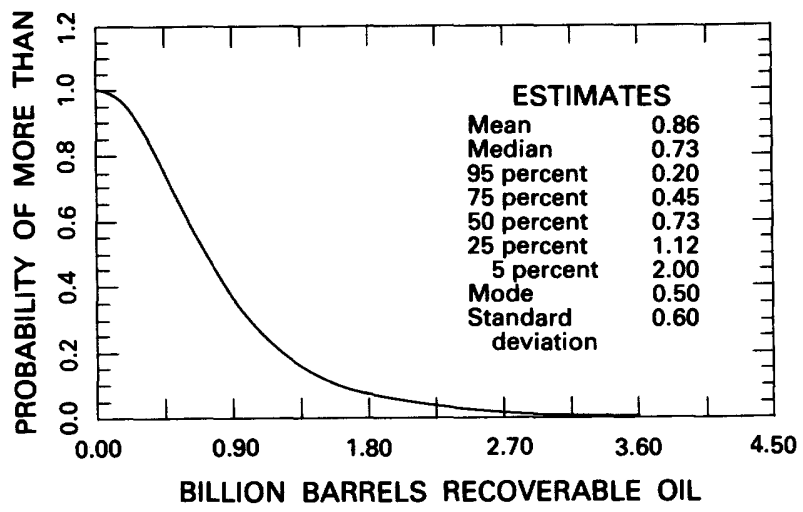

Figure 19.-Northwest European region, Southern North Sea Basin, subregion A, recoverable oil. (Unconditional assessment; date-2/23/82.)

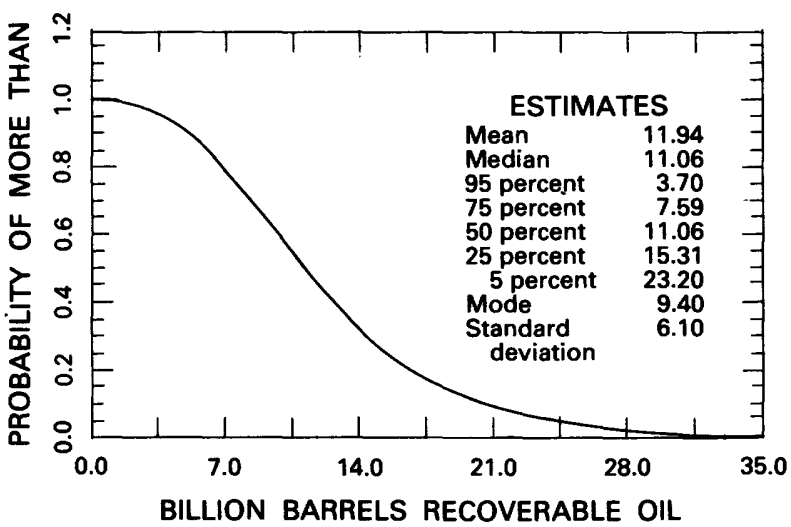

FIGURE 21.-Northwest European region, subregions B+E, Viking and Central Grabens, recoverable oil. (Unconditional assessment; date-2/23/82.)

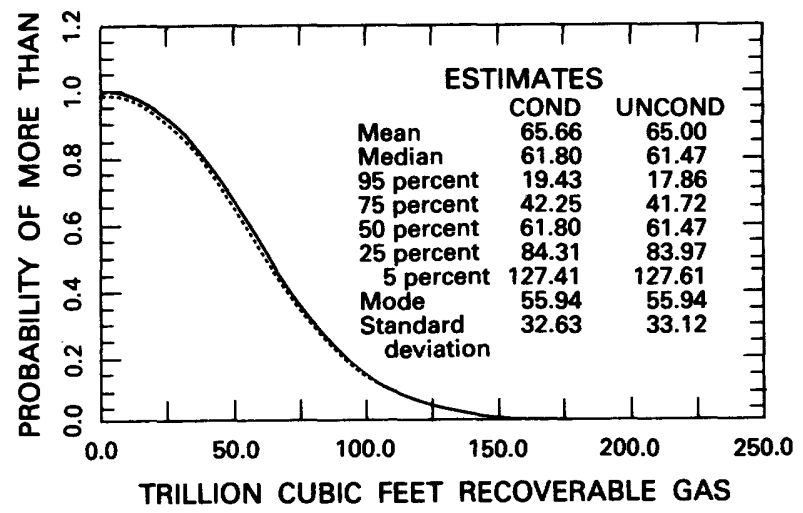

Figure 18.-Northwest European region, north of $62^{\circ} \mathrm{N}$., subregions $\mathrm{C}+\mathrm{D}$, aggregate recoverable total gas. (Conditional assessment-solid line; unconditional assessment-dashed line; date-7/13/82.)

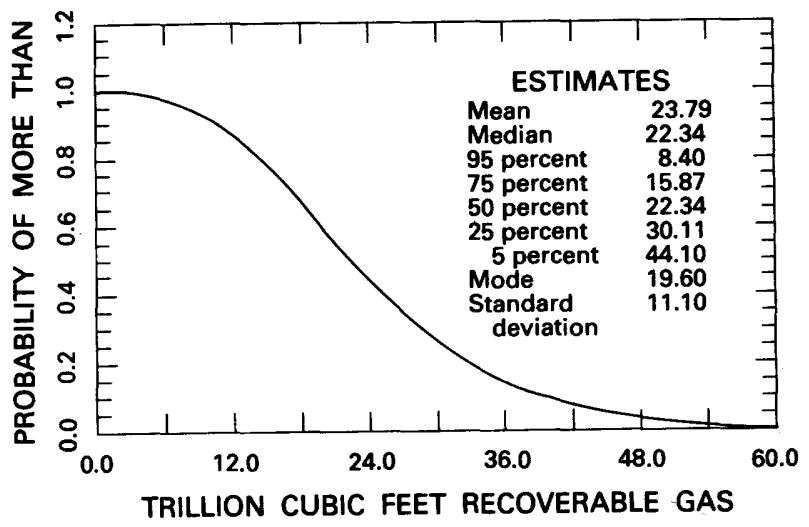

Figure 20.-Northwest European region, Southern North Sea Basin, subregion A, recoverable total gas. (Unconditional assessment; date-2/23/82.)

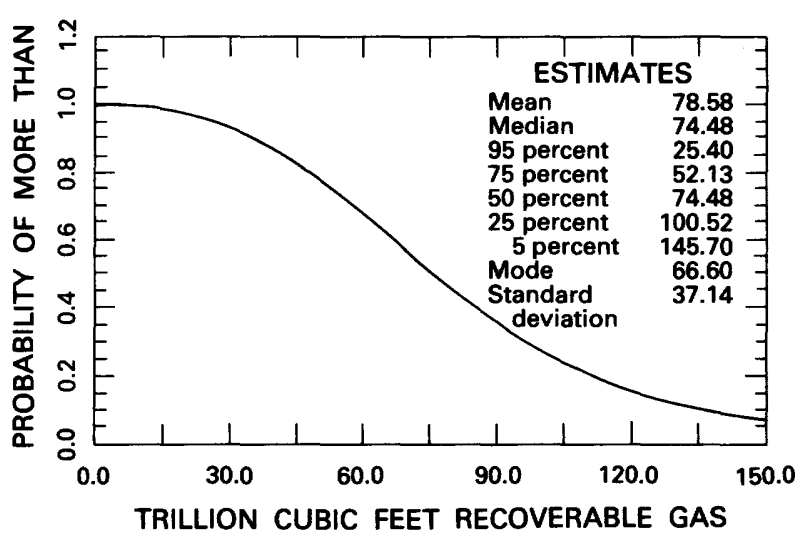

FiguRE 22.-Northwest European region, subregions B+E, Viking and Central Grabens, recoverable total gas. (Unconditional assessment; date-2/23/82.) 


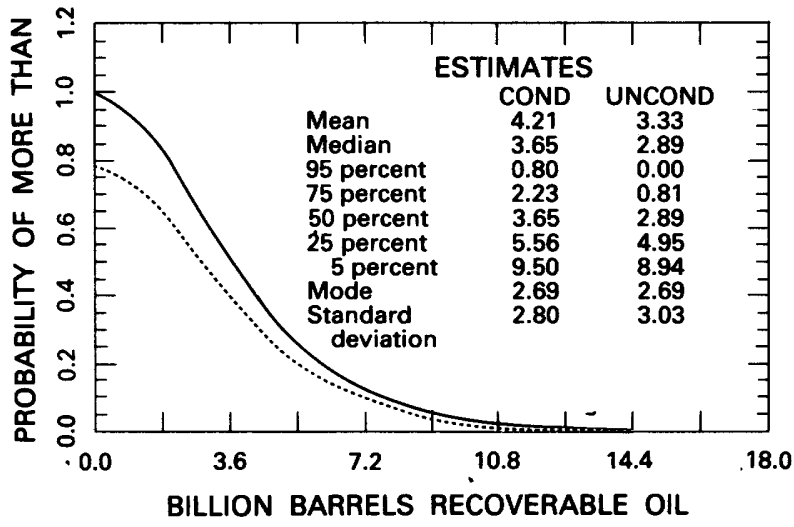

FIGURE 23.-Northwest European region, subregion C, north of $62^{\circ} \mathrm{N}$., southern sector, recoverable oil. (Conditional assessment-solid line; unconditional assessment-dashed line; date-7/13/82.)

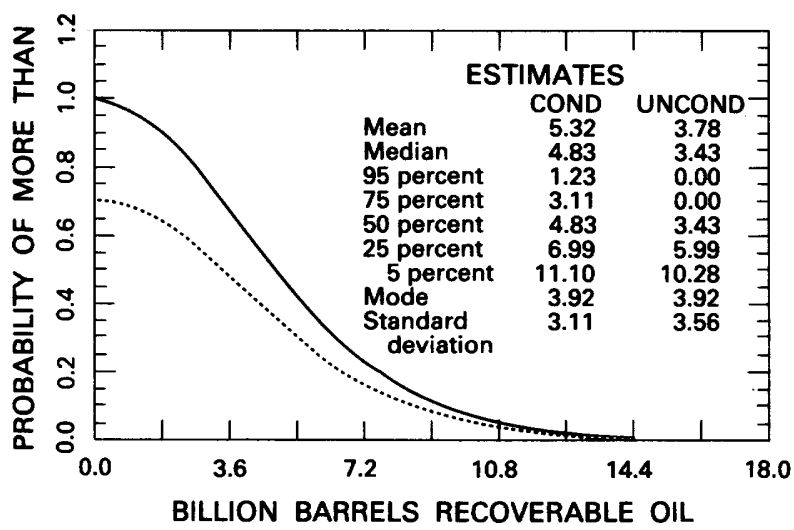

FIgURE 25.-Northwest European region, subregion D, north of $62^{\circ} \mathrm{N}$, northern sector, recoverable oil. (Conditional assessment-solid line; unconditional assessment-dashed line; date-7/13/82.)

- The Southern North Sea Basin geologically is completely different from the rest of the North Sea and appears to be a Klemme type $2 \mathrm{~A}$ complex basin; specific basin analogs include the Ergs Oriental and Occidental in Algeria and the West Siberian Basin in the U.S.S.R.

- In both the Viking and Central Grabens and in the Southern North Sea Basin, a number of discoveries are under evaluation-some 36 in the former and 45 in the latter. In the assessment, we assume that most of these discoveries represent a marginal economic field-size potential, and their exclusion from the discovered reserves does not significantly affect the estimate of undiscovered resource potential.

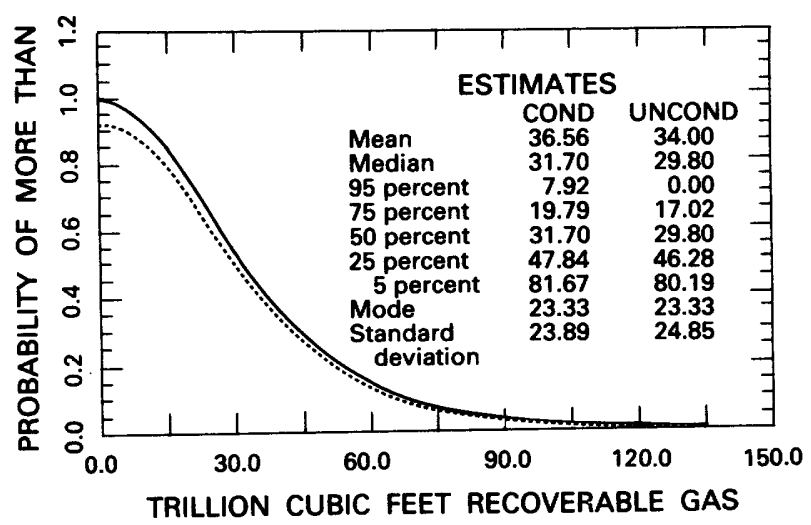

FIGURE 24.-Northwest European region, subregion C, north of $62^{\circ} \mathrm{N}$., southern sector, recoverable total gas. (Conditional assessment-solid line; unconditional assessment-dashed line; date-7/13/82.)

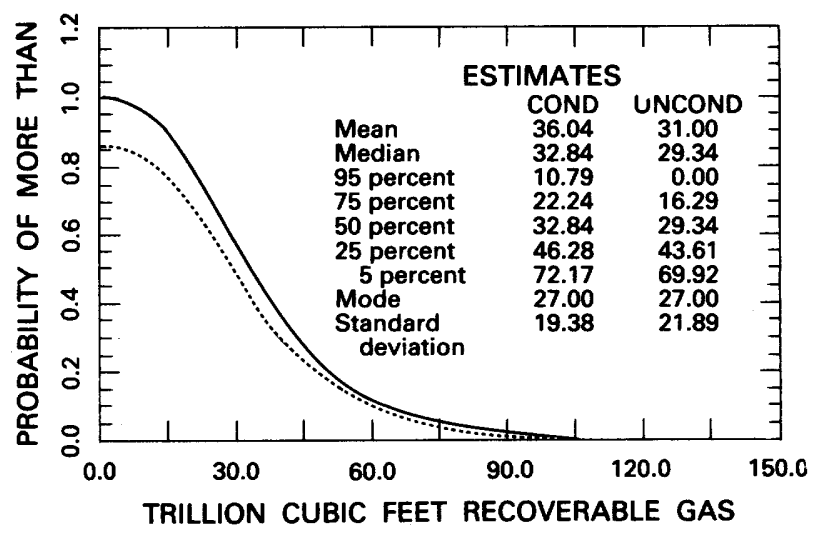

FiguRE 26.-Northwest European region, subregion D, north of $62^{\circ} \mathrm{N}$., northern sector, recoverable total gas. (Conditional assessment-solid line; unconditional assessment-dashed line; date-7/13/82.)

- Broad areas for which there are little data, lying between and west of the British Isles, are included in the assessment, but regional analysis suggests that those regions have lesser potential as compared with the heart of the North Sea. To the south, this would appear to be owing to facies changes in the prime Jurassic source rock and possibly to inadequate burial depth. To the northwest, however, due west of the Shetland Islands, a giant field has been discovered on the Rona Ridge (approximately $4 \times 10^{9} \mathrm{bbl}$ in place), but the oil is heavy, $22^{\circ}-25^{\circ} \mathrm{API}$, the result of which is that recovery percent is limited, and the relatively shallow depth of burial poses difficult produc- 
tion problems. Exploration undoubtedly will continue in this area, however.

- The assessment area extends marginally into the area that probably belongs geographically to the Barents Sea. The geological characteristics that make the North Sea proper a productive area do not extend significantly into the Barents Sea; hence, the assessed potential for that area is minimal.

- Prime areas thought to have undiscovered potential appear to heavily favor Norway, considering the as yet modest exploratory effort in the northeast Viking Graben area, the Bergen High, and the Horda Basin. The very large offshore region to the north of $62^{\circ} \mathrm{N}$. latitude suffers from increasing water depth loptimum geology would appear to lie between 600 and $1,200 \mathrm{ft}$ of water depth) and excessive source rock depth of burial. Both factors decrease economic potential, the former because of increasing costs and the latter because the area is rendered gas prone. The two discoveries to date have been gas and gas condensates. The Bergen High and Horda Basin may suffer from either absence or immaturity of source rock.

- Areas of petroleum potential were estimated under the assumption of normal to slightly above-normal temperature gradients. Because we think the temperature gradient may in fact have been higher, we consider that assumption to have biased the estimate slightly toward oil.

\section{REFERENCES CITED}

Crovelli, R. A., 1981, Probabilistic methodology for oil and gas resource appraisal: U.S. Geological Survey OpenFile Report 81-1151, 77 p.
Dolton, G. L., and others, 1981, Estimates of undiscovered recoverable conventional resources of oil and gas in the United States: U.S. Geological Survey Circular 860, 87 p.

Hallam, A., 1980, Sedimentation and tectonics in relation to oil occurrence in the North Sea, in Mason, John F., ed. Petroleum geology in China, PennWell Books, Penwell Publishing Co., Tulsa, Okla., p. 171-179.

Illing, L. V., and Hobson, G. D., 1981, eds., Petroleum geology of the Continental Shelf of North-West Europe, Proceedings of the second conference: March 4-6, 1980, Institute of Petroleum, London: Heyden and Son, Ltd., $539 \mathrm{p}$.

Jorgensen, F., and Navrestad, T., 1981, The geology of the Norwegian shelf between $62^{\circ} \mathrm{N}$. and the Lofoten Islands, in Illing, L. V., and Hobson, G. D., eds., Petroleum geology of the Continental Shelf of North-West Europe, Proceedings of the second conference: March 4-6, 1980, Institute of Petroleum, London: Heyden and Son, Ltd., p. 407-413.

Klemme, H. D., 1981, Types of petroliferous basins, in Mason, John F., ed., Petroleum geology in China, PennWell Books, Tulsa, Okla., p. 101-115.

Ronnevik, H. C., 1981, Geology of the Barents Sea, in Illing, L. V., and Hobson, G. D., eds., Petroleum geology of the Continental Shelf of North-West Europe, Proceedings of the second conference: March 4-6, 1980, Institute of Petroleum, London: Heyden and Son, Ltd., p. 395-406.

Ulmishek, G. F., 1982, Petroleum geology and resource assessment of the Timan-Pechora basin, USSR, and the adjacent Barents-Northern Kara shelf: Argonne National Laboratory, ANL/EES-TM-199, 197 p.

Woodland, A. W., 1975, ed., Petroleum geology of the Continental Shelf of Northwest Europe, v. 1: Applied Science Publishers.

Ziegler, P. A., 1980, Hydrocarbon provinces of the Northwest European Basin, in Miall, A. D., ed., Facts and principles of world petroleum occurrence, Canadian Society of Petroleum Geologists Memoir No. 6., p. 653-703.

1981, Evolution of sedimentary basins in North-West Europe, in Illing, L. V., and Hobson, G. D., eds., Petroleum geology of the Continental Shelf of North-West Europe, Proceedings of the second conference: March 4-6, 1980, Institute of Petroleum, London: Heyden and Son, Ltd., p. 3-39. 